\title{
What drives the vulnerability of pastoralists to global environmental change? A qualitative meta-analysis
}

\author{
Feliu López-i-Gelats ${ }^{1,2^{*}}$, Evan D.G. Fraser ${ }^{3}$, John F. Morton ${ }^{4}$, Marta G. Rivera-Ferre ${ }^{1}$ \\ ${ }^{1}$ Agroecology and Food Systems Chair, Environment \& Food Dpt. - Faculty of Sciences and Technology, University \\ of Vic-Central University of Catalonia (Spain) ${ }^{2}$ Center for Agro-Food Economy and Development (CRED-UPC- \\ IRTA) (Spain) ${ }^{3}$ Department of Geography, University of Guelph (Canada) ${ }^{4}$ Natural Resources Institute, University \\ of Greenwich (United Kingdom)
}

\begin{abstract}
The long-term viability of pastoralism has been a constant theme for discussions. The progress of knowledge on the sustainability of pastoralism under global environmental change has been notable in the last years. To better characterize this vulnerability, we have examined the existing scientific knowledge about the three dimensions of vulnerability, being exposure illustrated by the existing climate trends and non-climate transformations, sensitivity by the impacts of these on pastoral resources and pastoral land conversions, and adaptation by the adaptation strategies developed by the pastoral communities. A qualitative meta-analysis was conducted to explore patterns and trends across the literature. From this, six different pathways of vulnerability being followed by pastoral communities were identified: Encroachment, Re-greening, Customary, Polarization, Communal and No-alternative. The results point that the livelihood options of pastoralists are generally becoming narrower. Four major forces are identified as exerting determinant influence on the co-production of the vulnerability of pastoralism: (i) the double exposure to climate and non-climate transformations, (ii) the persistence of unfavorable development policies, (iii) the great vitality of adaptation, and (iv) the multifaceted role of markets. We point that it is crucial to distinguish between the component of vulnerability inherent in any economic activity devoted to the use of natural resources, which is the usual business of pastoralism, and the component of vulnerability linked to external forces that disturb the usual working of the pastoral production strategies.
\end{abstract}

Keywords: adaptation, climate change, land encroachment, Qualitative Comparative Analysis, high reliability system

\section{Acknowledgments}

FLG has a Juan de la Cierva postdoctoral contract financed by the Spanish Ministry of Economy and Competitiveness, and financial support by SUR and Departament d'Economia i Coneixement of the Catalan Government.

* Corresponding author. Tel.: +349388155 19. Fax: +34 938814307

E-mail address: feliu.lopez@uvic.cat (F. López-i-Gelats).

Agroecology and Food Systems Chair, Environment \& Food Dpt. - Faculty of Sciences and Technology, University of Vic-Central University of Catalonia, C. de la Laura 13, 08500 Vic, Spain 


\section{Introduction}

6

The long-term viability of pastoralism has been a continuous theme for discussions and the progress of knowledge on the survival of pastoralism under global environmental change has been notable since the mid-2000s. Thus, while some assert that pastoralism is disappearing due to internal causes - e.g. that the current climate change falls beyond its adaptive range (Steen, 1994; Markakis, 2004; Sandford, 2006) - others trace the foundations of the pastoral fragility back to its settings in marginal areas and unfavorable environmental conditions (Jónsson, 2010). This combination of factors is said to create "multiple stressors" that undermine pastoralism (Thébaud and Batterbury, 2001; Mihlar, 2008). Others disagree and argue that pastoralism is better suited than other land uses to do well under changing environmental conditions (Bradley and Grainger, 2004; Davies and Nori, 2008; Jones and Thornton, 2008). In line with this, greatly varying and sometimes directly contradictory advice, a range of policy recommendations oriented towards pastoral peoples coexist in the literature. There is great controversy whether the development policies directed to pastoralists, particularly from states and development agencies, to change their lives, settle and modernize, are adequate (Scoones, 1995; Chatty and Colchester, 2002; Morton, 2010a; Dong et al., 2011; Krätli et al., 2013). Opposed positions can be found on either the beneficial or the harmful effects of development interventions such as economic diversification, market integration, humanitarian relief, education or sedentarization schemes (e.g. Krätli and Dyer, 2009; Valdivia et al., 2010; Rivera-Ferre and López-i-Gelats, 2012). This does not help to stop the implementation of inadequate development policies, which eventually constitute additional barriers for pastoral livelihood and management. It is thus relevant to examine what drives pastoralists' vulnerability to global environmental change and its implications. Specifically, little attention has been paid to the complex and location-specific nature of pastoralism (Hinkel, 2011), as well as to the implications of non-climate drivers on the continuity of pastoralism (Morton, 2010a; Below et al., 2012; McDowell and Hess, 2012). In view of that, the purpose of this paper is to identify both the multiple drivers affecting pastoralism under global environmental change and the diverse 'pathways of vulnerability' being followed by pastoralists, and defined as the diverse development trajectories followed by specific pastoral peoples under different global environmental change conditions. Patterns and trends across the literature on the viability of pastoralism under global environmental change were explored through a systematic review and meta-analysis. In particular, we focused on scientific literature comprising case studies based on primary data. 


\section{The notion of pastoral vulnerability}

32 We start by recounting a brief genealogy of the most influential lines of thought in defining pastoral vulnerability. The first studies can be traced back to the 1930s, 1940s and 1950s with the works of Troll $(1931,1966)$ on human geography of extreme climates, and the ethnographic works of Evans-Pritchard (1940) and Stenning (1959) on pastoral organization in arid and semiarid Africa. However, it was not until the 1970s and 1980s that pastoral research took off. Research was dominated by cultural ecology approaches aiming to understand in what ways pastoralists responded to environmental change. Attention was placed on the effects of environmental stress on the management and organization of pastoralists, particularly in Africa and Mideast. Based on mobility, diversity of species and management flexibility, these studies underlined the pastoral rationality in responding to changing and patchy resource distribution (Dyson-Hudson, 1972; Dyson-Hudson and McCabe, 1985; Fratkin, 1986; McCabe, 1990). Despite the in-depth understanding provided by these fieldwork-based studies, this social anthropological approach exerted a marginal influence on policy development (Morton 2010b). During that period development policies were fundamentally driven by the conviction that pastoral lands were unoccupied or poorly utilized, justifying their appropriation for more appropriate land uses (Nori et al., 2008).

In contrast, the influence on policy arenas of the ecological approaches that followed Hardin's 'tragedy of the commons' thesis (1968) was overwhelming. Following the Lotka-Volterra model of predator-prey dynamics, the tendency of pastoralists to maximize their herds, together with growing populations, was regarded as leading to overgrazing, desertification and environmental degradation. Pastoralism was viewed as disturbances in the rangeland system rather than an inextricable part of it (Little, 1994). The notion of carrying capacity was brought to the fore. Pastoralism was then pictured not only as economically unproductive, but also as environmentally damaging and socially backward (Swift, 1996; Nori et al., 2008). Dismantling common property, destocking and endorsing commercial ranching were seen as the fundamental pillars where policy interventions should rest to stop rangeland degradation and enhance the pastoralists' socio-economic development (Lamprey, 1983; Simpson and Evangelou, 1984). Initiated in Western mentalities for Western environments, this line of thought soon became the world dominant doctrine among policy-makers and developers and it is still exerting a major influence nowadays.

Nonetheless, criticisms of this thesis emerged questioning the meaningfulness of the notion of carrying capacity in changing environments and claiming the need to distinguish in land tenure between communal and open access. Building on this, two main critical perspectives rejecting environmental determinism and stressing the role of wider driving forces in understanding the pastoral-rangeland relations can be identified. The first one centered on political processes, which described trends of economic stratification within pastoral groups because of the contact with sedentary agricultural states and resultant processes of political encapsulation of pastoralists (Asad, 1970; Salzman, 1974; Marx, 1977; Equipe Écologie 

that both pastoral rationality and policy development had to be rethought in light of the ecological evidence that most of the rangelands are fundamentally unstable ecosystems, where the equilibrium theory does not apply and uncertainty is the norm (Sandford, 1983; Ellis and Swift, 1988; Behnke et al., 1993; Behnke, 1994; Scoones, 1995). For the proponents of the new range ecology the equilibrium assumption lying behind traditional range ecology and policy development, based on enhancing predictability and single function system, through initiatives such as erecting fences, favoring sedentarization and meat market orientation, is simply a replication of the dynamics and solutions more appropriate for temperate and more predictable climates. They argue that because of decoupled plant-herbivore interactions, pastoralists have little impact on rangelands (Fernández-Giménez and Allen-Diaz, 1999; Sullivan and Rohde, 2002; Lind et al., 2003; Derry and Boone, 2010). Thus, pastoral vulnerability is fundamentally viewed as of external origin, being resource access more central than stocking rates.

Based on the premises of the new range ecology, some authors have developed a pastoral economic model alternative to the conventional risk-aversion archetype, which sees pastoralism as a high-reliability system (Roe et al., 1998; Krätli, 2008; Roe and Schulman, 2008). Rather than picturing pastoralism as a coping strategy to deal with inadequate resource base, it is seen as an economic strategy distinctive of unpredictable environments and developed to exploit the variable and patchy resource distribution of rangelands. Pastoralism is seen as operating not by avoiding risk, but by employing it as the very base of production. They believe that the pastoral economic system is 'proactive, methodical and geared at value creation and maximization, rather than mere survival' (Krätli and Shareika, 2010). To them, analytical tools that highlight stability and uniformity and consider asymmetric distribution of resources as undesired disturbances are not adequate to analyze pastoral systems and design development policies. However, despite substantial progress in the understanding of rangeland ecology and pastoral rationality, the emergence of climate change as a central policy issue, in conjunction with the evidence of numerous pastoral development policy failures, is fueling once again a new wave of claims that question the continuity of pastoralism as a result of its internal incapacity to deal with the current environmental variability and prevent poverty (Sandford, 2006; Morton, 2010b). Academics from multiple disciplines have long been interested in understanding how nature and society are interlinked. The notion of vulnerability we employ results from this endeavor, with recent integrated approaches, which picture the nature-society interlinkages as coupled human-environment systems and highlight the double essence of vulnerability as socially and naturally produced, being increasingly adopted to understand the implications of global environmental change (e.g. Turner et al., 2003; Lonescu et al., 2009; Fraser et al., 2011; Ribot, 2011). Following this literature, to understand the implications of global environmental change for the viability of pastoralism, we adopted an integrated notion of vulnerability, which comprises exposure, sensitivity and adaptation as the three fundamental dimensions of vulnerability 
(Kasperson et al., 2005; Adger, 2006; Gallopín, 2007). Exposure is seen as the extent to which pastoralism is subject to perturbations. Here we considered both climate trends and non-climate transformations associated with global environmental change. Sensitivity refers to the degree to which previous transformations impact on pastoralism. Here we paid attention to impacts on pastoral livelihoods, specifically in terms of increased or decreased access to pastoral resources and favorable or detrimental land conversions for pastoralists. Adaptation is conceived as the capacity of pastoralists of minimizing the damage or benefiting from the impacts occurring. Finally, pathways of vulnerability are seen as specific combinations of exposure, sensitivity and adaptation being undergone by certain pastoral peoples.

\section{Methodology}

Following recent advances in the investigation of global environmental change (Young et al., 2006; Polsky et al., 2007; Rudel, 2008), we conducted a combination of systematic review and meta-analysis with the methodology of qualitative comparative analysis (QCA). To do this, we used the actual published studies as our data (rather than the data used by each study), and this enabled us to pool non-standardized and qualitative information (Hofmann et al., 2011). The QCA metaanalysis enables the aggregation of findings of local studies to reveal general trends, which in this case are employed to identify and characterize the diverse pathways of vulnerability being experienced by pastoral peoples. Despite increasingly being used in the global environmental change field (e.g. Geist and Lambin 2004; Evans et al., 2011; van Vliet et al., 2012; Lugnot and Martin, 2013), this approach has never been applied to pastoral issues.

The implementation of the QCA systematic review and meta-analysis followed these steps:

(1) characterization of the research question, namely 'what drives pastoralists' vulnerability to global environmental change';

(2) description of the inclusion criteria for case studies, specifically containing primary and empirical data on the three dimensions of vulnerability for a given pastoral community, that is exposure, sensitivity and adaptation;

(3) selection of the relevant literature, which was conducted through the Scopus and Web of Science search engines on $14^{\text {th }}$ October 2013 to select English-speaking papers published in peer-reviewed scientific journals, by means of the following equations (pastoral* OR herd*) AND ("climat* chang*" OR "climat* varia*") AND (adapt* OR vulnerab* OR risk OR resilient* OR uncertaint*), and (pastoral*) AND ("climat* chang*" OR "climat* varia*"); that is, we searched for papers containing the keywords of pastoralism or herd, and climate change or climate variability, and adaptation or vulnerability or risk or resilience or uncertainty.

(4) extraction from the selected papers of the case studies fulfilling the inclusion criteria (table 1);

(5) selection of the yes/no variables characterizing the three dimensions of vulnerability, and coding of the case studies with them accordingly, through a process of iterative rereading and recoding of the case studies; 

significant combinations of them that tend to be described in association, which we interpreted as pathways of vulnerability, through statistical analysis of the characterization of the selected case studies by the selected variables.

The literature search (step 3, above) resulted in the initial choice of 170 papers. A careful examination of the fulfilment of the inclusion criteria reduced the initial selection to 74 papers, comprising the 75 case studies that integrate the final selection (Table 1). Through meticulous reading and rereading of them, the variables characterizing the three dimensions of vulnerability were identified and the case studies coded accordingly. Once a new element dealing with the vulnerability of pastoralism was identified in the reading of a given paper, that is in the examination of a particular case study (e.g. occurrence of droughts, reduced access to rangelands, or water storage as an adaptation strategy), it suddenly became a new variable, and the rest of the papers were then reread and the rest of the case studies recoded considering this new variable, specifically indicating the description or not of this new element. This iterative process resulted in the end in the generation of 185 yes/no variables, with which the whole selection of case studies was finally coded. The dimension of exposure specifically comprised evidence in the cases studies of the occurrence or not of both climatic and non-climate transformations -embracing policy and institutional, sociocultural, economic, demographic or biophysical groups of variables. Sensitivity included groups of variables on the occurrence or not in the case studies of impacts on pastoral livelihoods, indicated as increased or decreased access to pastoral resources and the occurrence or not of land conversions with either favorable or detrimental effects for pastoralists. The dimension of adaptation was covered by several groups of variables concerning the description or not in the case studies of activities and practices developed to benefit pastoralists from undergoing transformations or minimize undesirable effects on them of certain impacts -namely, mobility, diversification, communal pooling, market exchange, intensification, storage, extensification and aid. Finally, three additional variables indicating the recent evolution of the number of pastoral households in the case studies were also used, distinguishing between increasing number, stable or no data available, and decreasing number. was conducted, specifically a combination of Multiple Correspondence Analysis (MCA) and Cluster Analysis. MCA was applied to reduce the initial quantity of variables to a set of new factors. Initially we removed any variables that had a frequency lower than $5 \%$, that is those variables that were identified in less than $5 \%$ of case studies. Then we used the MCA to identify 32 first factors that explained $80.63 \%$ of the total explained variance. The Cluster Analysis, using Ward's method based on Euclidean distance, was then carried out to organize the cases studies in different groups according to their similarity using the factors obtained in the MCA. Stemming from the particular coding of the case studies comprising 
groups were interpreted as pathways of vulnerability. In order to describe each group, significant differences among them and per each variable were checked using the Chi-square test. All statistical analyses were conducted with the software package SPAD 5.5 (SPAD 5.5, 1996).

\section{Results}

The 75 case studies examined occur in nine regions. Mongolia, Himalaya-Pamir, Arctic, Western Africa and Eastern Africa are the regions more represented in our sample. European mountains, Andes, Southern Africa and Northern Africa each have fewer cases (Fig. 1). In terms of countries, Kenya, China, Ethiopia, Mali, Mongolia and Peru are those where most case studies were documented. The pastoralists of the Horn of Africa and Mongolia are clearly those most present in the sample of literature considered here, with Kenya, Ethiopia, China and Mongolia comprising nearly one-half of the reported case studies (Fig. 2). Remarkably, so far, there are pastoral peoples that have been largely dismissed by the vulnerability literature, such as Middle Eastern pastoralists, Turkmen and Kazakh pastoralists or Eastern Europe herders - see Blench (2001) for an exhaustive list of world pastoral peoples.

\section{[FIGURE 1 ABOUT HERE]}

\section{[FIGURE 2 ABOUT HERE]}

The coding of the case studies comprised in our sample, with the 185 variables identified, provided an in-depth characterization of the three dimensions of the vulnerability of pastoralism under global environmental change. Concerning the exposure of pastoral peoples to climate trends, overall changes in the seasonality of precipitation and drought were identified as the most likely ways that pastoral peoples are exposed to observed climate change. This was followed by rising temperatures, floods, snowstorms, strong winds, glacier retreat, extreme winter and less snow. In our sample pastoral peoples are also largely exposed to non-climate drivers, specifically ill-conceived or policies marginalizing pastoralism, changing traditional institutions such as the dismissal of elders' councils, violent conflicts, increased marketization, encroachment of agriculture on pastoral lands, population growth and emigration, expansion of animals representing a potential damage for the interests of pastoralists, and forest and shrub encroachment on grasslands (see Appendix A). As regards sensitivity, in revisiting our sample of case studies, the occurrence of multiple transformations on pastoral peoples was notorious. In terms of impacts on pastoral livelihoods, decreased access to rangelands, growing difficulties of moving and conducting customary management practices, decreased size of the herds, decreased health status of the animals, and increased access to market should be mentioned. In terms of the effects of land conversions on pastoral peoples, the detrimental effects of pastoral land degradation and privatization, and encroachment on pastoral land by agriculture, nature reserves or urbanization processes should be underlined (see Appendix B). Regarding 
adaptation, in our sample of case studies multiple strategies were described as being developed by pastoral peoples to benefit from or to minimize the damage of the impacts coming along with global environmental change. Those distinguished by being more commonly reported were herd mobility and changing grazing patterns, the combination of pastoral activity with other gainful activities, reciprocal social relations among pastoralists and communal planning and herding, further developing trade through market access, pasture enclosure, herd accumulation, abandonment of the pastoral activity, and turning to governmental and non-governmental aid (see Appendix C). Finally, the recent evolution in the number of pastoral households in our sample of case studies points towards a general decreasing trend (see Appendix D).

\subsection{Narratives of the diverse pathways of vulnerability of pastoralism}

In the interpretation of the results, it is worth noting that, as shown in section 2 , there has been an evolution in the dominant lens through which the viability of pastoralism is framed. Successive narratives show a bias towards different aspects. It should be acknowledged that the current meta-analysis fundamentally covers the renewed interest in the viability of pastoralism that is taking place since mid-2000s, with the emergence of climate change as a major policy issue. However, this framing has not brought about uniformity in reporting or analyzing vulnerability factors. Using QCA and Cluster Analysis, we have been able to identify from the reviewed papers on the viability of pastoralism, six distinct pathways of vulnerability, that is six different specific combinations of exposure, sensitivity and adaptation, distinguished as being experienced by pastoralists in different parts of the world (Table 1):

i. Encroachment, distinguished by the loss of control of pastoral land in a context of persistent unfavorable development policies and declining operationalization of pastoral production strategies and institutions;

ii. Re-greening, distinguished by the incidence of afforestation in a context of acute non-climate transformation and declining access to pastoral resources to which pastoral communities mainly respond through emigration and diversification;

iii. Customary, distinguished by the larger preservation of pastoral production strategies and institutions, and minor exposure to non-climate transformations, specifically those dealing with land, mobility and agriculture;

iv. Polarization, distinguished by the shifting towards ranching, through the concentration of the pastoral production strategies where conditions enable the adoption of intensive rearing and abandoning the rest of the land;

v. Communal, distinguished by the great aptitude for adaptation to major non-climate transformations through communal pooling; 

increased input use in the pastoral activity.

\section{i. Encroachment}

218

The first pathway that emerged from the MCA and Cluster analysis, which we labeled 'encroachment', refers to the way in which pastoral lands are being broadly encroached upon by other activities. With $39.5 \%$ of the case studies, the declining access to crucial pastoral resources and the political marginalization of pastoralists are defining features of this pathway. It is fundamentally identified in Eastern Africa and Mongolia. Concerning exposure, drought and changes in seasonality are identified as the most pressing climate trends in these case studies. Originating in either policy, economic, social or ecological domains, non-climate transformations are also profusely described as playing a crucial role. It is reported that land-use policies, sedentarization schemes and extension services are often implemented in ways that marginalize pastoral livelihoods, while prioritizing other interests. The non-recognition of the land rights of pastoralists and the associated encroachment upon rangeland areas of new land uses, such as agriculture, infrastructures, urban areas, ranching, tourism or mining, is dramatically identified in these case studies (e.g. Wang and Zhang, 2012; Goldman and Riosmena, 2013). This pathway is also characterized by increased integration of pastoralists within the market economy and by the occurrence of remarkable transformations in traditional institutions. Complex demographic trends are also observed, mainly led by population growth and emigration.

Concerning sensitivity, land privatization combined with the development of agriculture, irrigation schemes, ranching, mining, nature reserves, game reserves and urbanization are mentioned as causing wide encroachment upon traditional rangeland areas causing massive detrimental effects for pastoral groups. Thus dramatic land privatization and land degradation are identified, which not only entail reduced availability of rangelands for pastoralists, but also undermine their access to water, labor, mobility, social networks and even food. The quantity of livestock also diminishes, while its productivity seems to rise. On the contrary, market access is strongly enhanced, but in combination with insecurity and social unrest. adaptation strategies being implemented by pastoral households undergoing this pathway. Herd mobility and changing 

such as communal planning and herding, bartering, labor exchange and information gathering, including early warning systems or improved weather forecasting, are reported. Enhanced market exchange is also broadly identified, mainly conducted by improved market access and trade, but also through input purchase, and in case of need, by participating in credit schemes and selling assets (e.g. livestock). Sedentarization and exiting pastoralism is also described as a common adaptation strategy. Pasture enclosure, adoption of feed crop agriculture and stall feeding, and shifting to irrigated farming are strategies less commonly implemented by these pastoral groups. This is also the case of receiving aid. Despite these strategies, in this pathway of vulnerability the number of pastoral households is largely decreasing.

\section{ii. Re-greening}

The second pathway that emerged from the statistical analysis was characterized by the recent increase in the number of trees observed in large areas of West African Sahel over the last 20 years. With 3.9\% of the case studies, it is the least common pathway among the case studies. We labeled this the 're-greening' pathway, being distinguished by large biophysical transformations, specifically afforestation and drying lakes (e.g. Djoudi el al., 2013). This pathway is also characterized by the major incidence of unfavorable policies for pastoralists and encroachment on pastoral land. Droughts, changes in seasonality and sand-dust storms are the most critical climate trends identified. As in the previous pathway, non-climate drivers play a central role. Additional non-climate transformations described include the implementation of governmental and non-governmental policies oriented towards land management, sedentarization of pastoral groups, and the provision of pastoral extension services and assistance. It is generally observed in these case studies that the implementation of these policies tend to marginalize pastoral livelihoods and entail the provision of services in a manner inadequate for pastoralists to benefit from them. Increased social unrest, emigration, agriculture expansion and infrastructure development are also identified as generating major effects on pastoral livelihoods. pastoralists of rangeland degradation, rangeland privatization and conversion of rangelands into irrigated agriculture, and the favorable effects for pastoralists of increased afforestation, which is seen as providing pastoralists with additional fodder and forest product harvesting (e.g. Brockhaus et al., 2013). These impacts are described in combination with notable decrease in the observance of customary pastoral practices, conservation of social networks and equity, pastoral 

described in this pathway.

Mobility and diversification are the main broad groups of adaptation strategies being implemented in this pathway. Enhanced herd mobility, changing grazing patterns, migrations of pastoral households, wage labor migration and sending remittances of members of the family, labor diversification, farm diversification and changes in livestock species composition, herd accumulation and restocking are crucial strategies in this pathway. Increased herd and household mobility, livestock diversification, adoption of diversified herd strategy managements, diversification in skill training, participation in the sale of new products, augmented use of inputs, high-yield breeds and modern technology, and the adoption of sedentary lifestyles are also widely observed adaptation strategies. Remarkable dependence on aid is also usually mentioned. In all case studies comprising this pathway the number of pastoral households is reported to be in decline.

\section{iii. Customary}

The third pathway identified in the statistical analysis was characterized by the existence of traditional pastoral practices and institutions well preserved from transformations detrimental to pastoral interests. We labeled it "customary". It comprised $13.2 \%$ of the case studies, mainly present in Eastern and Southern Africa. This pathway is distinguished by the fact that pastoral groups are exposed to fewer policies marginalizing them, which in turn goes with greater access to pastoral resources. Regarding exposure, changes in seasonality, droughts and floods are the most critical climate trends. The most prominent non-climate transformations to which pastoralists are exposed referred to inappropriate implementations of policies - in the domains of aid assistance, education and extension; development of infrastructures and population growth. However, the exposure to non-climate transformations in this pathway is minimal in comparison with the rest. This is particularly remarkable in terms of fewer occurrences of land policies and sedentarization schemes disregarding the pastoral interests, fewer changes in traditional pastoral institutions unfavorable to pastoralists, less marketization of pastoral economics, low emigration rates and reduced agricultural expansion upon rangelands. unfavorable land conversions. The low incidence described of privatizations of pastoral land is particularly remarkable, as is the notable incidence of conversions of pastoral land to agriculture and irrigated agriculture executed in a way advantageous for pastoralists (e.g. Notenbaert et al., 2013). This is consistent with the maintenance of pastoral mobility and social networks, as well as relatively low levels of land encroachment. Nonetheless, access to water and rangelands is still reported as decreasing. Also increased hardship in attaining food security and impoverished human health are 
Diversification accounts for the majority of adaptation strategies reported in this pathway. Diversification in the allocation of family labor, in farming activities and in the type of livestock raised is extensively described. This is identified together with notable involvement of pastoralists in market-driven strategies, specifically improved market access and trade, commercialization of new products, participation in credit schemes and destocking. In line with this, the identification in the case studies following this pathway of adaptation strategies associated with infrastructure development (e.g. water storage for agriculture), and the adoption of wage labor migration and child labor among pastoral families should be noted (e.g. Banerji and Basu, 2010; Mark et al., 2010; Ng'ang'a et al., 2011). In contrast, pastoralists are reported as being less likely to adopt strategies related to mobility and communal pooling than in the average of the selected case-studies. Particularly relevant of this pathway is the low involvement of pastoralists in adaptation strategies of extensification or intensification. A slight increase in the number of pastoral households is identified.

The fourth pathway emerging from the MCA and Cluster analysis, which we labeled 'polarization', makes reference to the observed coexistence in some regions, mainly in European mountains, of a double trend of concentration of agropastoral land ownership into larger properties in marginal areas and land subdivision into smaller properties in central areas. With $7.9 \%$ of the case studies, the coexistence of a double development trend among pastoralists distinguishes this pathway, first the adoption of intensive livestock rearing, and second land abandonment. Concerning exposure, the case studies following this pathway reported changes in seasonality and, to a lesser extent, droughts, rising temperatures and less snow as the most pressing climate trends. The existence of land-use and assistance policies affecting pastoralists, as well as remarkable tourism development in pastoral regions, certain level of population decrease and forest and shrub encroachment on pastoral land, are the most critical non-climate transformations to which the pastoralists following this pathway are exposed.

As regards sensitivity, in the case studies of this pathway almost no advantageous land conversions for pastoralists are reported, while detrimental effects for pastoral groups are described in association with rangeland abandonment and forest and shrub encroachment on pastoral land (e.g. Fernández-Giménez and Fillat, 2012a). In contrast, this is the pathway with the lowest level of rangeland degradation. This goes in line with the fact that these case studies show the least detrimental effects on rangeland access for pastoralists, as well as reduced effects on pastoral mobility, minimal social and food insecurities, and increase in forest access and wild fire risk. Market access is also on the rise. 

pathway. Thus, abandonment of distant pastures and withdrawing pastoralism are adaptation strategies being reported in these case studies together with adoption of stall feeding, use of larger land areas, implementation of feed crop agriculture and shifting from feed crop cultivation to pasture. This also goes with notable embracing of diversification strategies, indicating that when the conditions do not allow the intensification of pastoralism then this economic activity is conducted in combination with others. A general decline in the number of pastoral households is also observed in this pathway of vulnerability.

\section{v. Communal}

The fifth pathway identified by the statistical analysis, which we labeled 'communal', alludes to the capability of pastoralists to deal with undesired transformations through adaptations based on communal pooling. With $6.6 \%$ of the case studies, and mainly reported in Andes and Arctic regions, this pathway is characterized by a relatively successful management by pastoralists of the unfavorable policies oriented towards them and the detrimental effect on them of the encroachment of other activities upon pastoral lands. As regards exposure, rising temperatures, glacier retreat, changing seasonality in precipitations and less snow are those most critical climate trends observed in the case studies comprising this pathway. Remarkably not a single case of drought is reported in this pathway. The pastoral communities following this pathway are exposed to a combination of non-climate transformations, comprising policy, sociocultural, economic, demographic and biophysical trends. Specifically they include a persistent political marginalization of pastoralists, the implementation of sedentarization schemes, changes in traditional pastoral institutions, existence of social conflicts, increased marketization of the pastoral economy, development of infrastructures on pastoral land, expansion of mining in pastoral lands, population growth and emigration, expansion of wild animals potentially damaging for livestock, extinction of biodiversity and rising deforestation.

Concerning sensitivity, despite significant detrimental impacts in terms of reduced rangeland access and mobility, degradation of customary practices, less water availability, deteriorated social justice, weakened social networks, and limited access to forest and biodiversity; in this pathway it is also reported an increase in labor availability and a favorable development of irrigated pastures (e.g. Young and Lipton, 2006; Postigo et al., 2008). The encroachment upon pastoral marketization of the pastoral economics and social unrest. 

Communal-pooling-based adaptation strategies, such as reciprocal social relations among pastoralists, communal planning and herding, communal infrastructure development or bartering, are thus those most characteristic of this pathway (e.g. Postigo et al., 2008). However, the mobility and diversification groups of adaptation strategies are also extensively observed, specifically enhanced herd mobility, changing grazing patterns, migration of pastoral households and implementation of both farm and labor diversification. The commercialization of new products, adoption of sedentary lifestyles, water storage, shifting to irrigated farming and withdrawing pastoralism are also adaptation strategies extensively described in the case studies following this pathway. A general trend of increase in the number of pastoral households is reported in this pathway.

\section{vi. No-alternative}

The last pathway identified in the statistical analysis, which we labeled 'no-alternative', alludes to a lack of livelihood options other than pastoralism. With $28.9 \%$ of the case studies, and fundamentally described in Arctic, Himalaya-Pamir and Mongolia regions, this pathway is distinguished by the absence of economic alternatives to pastoralism in a context of a pastoral activity increasingly dependent on the use of purchased inputs. Regarding exposure, of the climate trends reported in the case studies comprising this pathway, change in seasonality and, to a lesser extent, rising temperatures, droughts and snowstorms are the most pressing ones. Whereas implementation of land use policies on pastoral lands, political marginalization of pastoralists, changes in traditional pastoral institutions, infrastructure development on rangelands and expansion of wild animals potentially damaging for livestock are the most critical non-climate transformations to which pastoralists are exposed. to rangelands, weakened capacity of pastoral mobility, damaged customary pastoral practices, decreased livestock quantity and quality, and growing overgrazing (e.g. Naess, 2013). The magnitude of the detrimental effects on pastoralists of rangeland degradation and land privatizations is also notable. It should be mentioned, however, that it is in this pathway where the lowest level of manifestations of social injustice are reported. implementation of diversification strategies, particularly acute as regards farm diversification. A low tendency to embrace wage labor migration and reciprocal social relationships is reported in this pathway; whereas mobility and communal pooling are groups of strategies notably described, specifically enhanced herd mobility, changing grazing patterns and 

and trade and commercialization of new products, pastoralists in this pathway increasingly turn to market to get supplies of inputs, high-yield breeds and technology. A moderate trend of decreasing the number of pastoral households is observed in this pathway of vulnerability.

\section{Discussion}

The statistical approach conducted in this paper reveals a diverse range of pathways of vulnerability followed by pastoral communities all over the globe. This illustrates a large spectrum of possible encounters between the climate trends and the non-climate transformations associated with global environmental change, the impacts on pastoral livelihoods of these trends and changes, and the adaptation strategies developed by pastoralists. To summarize the similarities and differences between all six pathways identified, figure 9 shows the relative importance for each of them of the three dimensions of vulnerability, being exposure illustrated by the number of climate trends and non-climate transformations reported, sensitivity by the number of impacts on pastoral resources and pastoral land conversions observed, and adaptation by the number of adaptation strategies described. From this we observe that the Encroachment pathway is characterized by abundant non-climate transformations and impacts on pastoral resources. This is also the case of the Re-greening pathway, which is also distinguished by going through numerous climate trends and abundant pastoral land conversions. The Customary pathway is defined by scarce non-climate transformations, which go with fewer impacts on pastoral resources and pastoral land conversions. The Polarization pathway is characterized by scarce impacts on pastoral resources and pastoral land conversions. The Communal pathway is distinguished by undergoing numerous non-climate transformations and minimal pastoral land conversions. Finally, the No-alternative pathway is defined by the limited number of adaptation strategies developed. Thus, four major forces have been distinguished as exerting crucial influence on the vulnerability of pastoralists: (i) the 411 double exposure to climate and non-climate drivers of transformation, (ii) the persistence of unfavorable development policies, (iii) the great vitality of adaptation, and (iv) the multifaceted role of markets. policy issue, and regardless of the apparent difficulties in accurately attributing specific impacts to specific transformations; the results of the QCA systematic review and meta-analysis indicate that the non-climate transformations to which pastoral groups are exposed exceeds, at least in number, the climate transformations (Table 2). Although the specific 
impacts of both kinds of exposure is difficult to determine, several studies mention the existence of a global commonality of the pressures to which pastoralists are exposed (Fratkin and Mearns, 2003; Anderson and Nuttall, 2004), with particular emphasis on non-climate drivers. All this is quite consistent with the thesis of the proponents of the new range ecology (e.g. Behnke, 1994; Scoones, 1995), as well as those picturing pastoralism as a high-reliability system (e.g. Krätli, 2008; Roe and Schulman, 2008), describing pastoral vulnerability as fundamentally driven by factors external to the standard pastoral business. In fact, Nori (2007) underlines that adequate land rights are the major global concern for pastoralists. Thus, it is not climate change by itself, but the combination of effects of climate change with additional policy, sociocultural, economic, demographic and ecological drivers - specifically encroachment upon pastoral land, ecological degradation, weakening of traditional systems of pastoral resource management and reciprocity, and economic stratification - that explains the increased vulnerability of pastoral groups to climate variations. As mentioned by Dong et al. (2011), pastoralism is experiencing a compound exposure.

Despite notable advancements in the comprehension of the rangeland dynamics and the rationality and sustainability of pastoralism, as illustrated in section 2, the persistence of unfavorable development policies oriented towards pastoralists is obstinate. As our results show, the occurrence of policies marginalizing pastoral groups, specifically concerning land issues, is largely the most important among non-climate pressures on pastoralism. In fact, low incidence of ill-conceived policies as in the Customary pathway - and strong sense of community - as in the Communal pathway - are central features of the pathways showing larger access to pastoral resources and less decrease in the number of pastoral households (Table 2). The literature identifies several reasons to explain the constant determination in the implementation of unfavorable development policies: (i) persistence of unfavorable narratives, representing pastoralism as economically unproductive, ecologically damaging and culturally backwards, and justifying dispossession and/or no need for public investments (Swift, 1996; McPeak and Little, 2006; Reinert et al., 2008; Harris, 2010); (ii) difficulties of finding appropriate ways of delivering public services for isolate, minority and mobile groups (Thébaud and Batterbury, 2001; Morton, 2010b); (iii) lack of political representation (Lister, 2004; Brocklesby et al., 2010; Morton, 2010a; Raleigh, 2010); (iv) governments' desire to control pastoral groups and the resources present in pastoral lands (Forni, 2003; Davies and Hartfield, 2007; Morton, 2010a; 441 Behnke and Kerven, 2013); (v) too much focus on technical investments, not always well adapted to the specific social and 442 ecological context of pastoralism (Scoones, 2004); and (vi) failures of well-intentioned policies, such as those ending in economic security traps (Hausner et al., 2011). Thus, a combination of vested interests on pastoral lands with intentional and unintentional ignorance on the pastoral ecological and economic rationality seems to lie behind the persistence of unfavorable policies oriented towards pastoralists. The deficient provision of basic public services, such as road infrastructures (Barton and Morton, 2001), education (Krätli and Dyer, 2009) or animal health services (Catley et al., 2004), 
As it is apparent that pastoralists all over the world are undergoing severe pressures, it is equally true that pastoral groups are actively facing these transformations. The number and diversity of adaptation strategies identified in this meta-analysis is remarkable, comprising different forms of mobility, diversification, communal pooling, market, storage, extensification and intensification practices. In fact, a total of 52 adaptation practices have been identified (see Appendix C). However, the great vitality of pastoral adaptation made evident by these results certainly blurs the distinction between coping and adaptation strategies, since this distinction was often not made apparent in the case studies. Furthermore, it must be kept in mind that pastoralism is an economic activity found in regions as different as mountains, drylands, tundra, deserts or steppes, where the seasonality of climate makes resources only available in sporadic or periodical concentrations. The nonexclusive tenure and land use system common to pastoralism (Behnke, 1994; Turner, 1999) is crucial to allow the movement of herds towards these ephemeral concentrations of resources. In fact, most rangelands in the world have been traditionally communally governed (Sandford, 1983; McCabe, 1990; Behnke et al., 1993; Fratkin, 1997). All this indicates that the nature of pastoral practices, such as mobility or communal management, is not merely coping or adaptation, but in some occasions is productive, characteristically of an economic activity specialized in exploiting transient concentrations of resources. The vitality of pastoral adaptation identified seems thus to be a consequence of a combination of coping and adaptation strategies with pastoral production strategies following the very rationality of the pastoral enterprise.

Trade and complementary production with neighbors is an essential part of the nature of pastoral livelihoods (e.g. Orlove, 1982; Abu-Rabia, 1994, Jina, 1999). However, as underlined by Khazanov (2009), while in the past they were not deliberately oriented to profit but to use-value, nowadays whether they like it or not, they are increasingly becoming involved in a monetary economy based on exchange value and livestock commoditization. The integration of pastoralists within the global market has brought about a rising influence on trading exchanges of factors that pastoralists cannot control. Also, the integration is often occurring in unfavorable conditions of state support for pastoralists (Khazanov, 2009). Thus, further market integration seems not to be always entirely desirable for pastoralists (e.g. Valdivia et al., 2010). The fact that in the coding of case studies conducted in this meta-analysis the market is conceptualized at the same time as a non-climate driver of transformation, as an impact of the transformations, and finally also as an adaptation strategy, illustrates the complex role market integration plays in the vulnerability of pastoralism. In some occasions it is seen as an additional stressor constraining pastoral livelihoods, while in some other occasions it is pictured as a desirable adaptation strategy to enhances pastoral livelihoods (Table 2).

[FIGURE 10 ABOUT HERE] 
477 The livelihood options of pastoralists are generally becoming narrower. Despite more and more evidence of increased 478 climate change (Field et al., 2014), the increased overall vulnerability of pastoralists is also a consequence of non-climate 479 drivers, specifically political marginalization and encroachment on pastoral resources. The vulnerability of pastoralists to 480 climate change is thus not entirely attributable to pastoralism, but also to the obstacles it encounters to develop its production strategies. Accordingly, it becomes critical to distinguish between different components of pastoral vulnerability. There is an inherent vulnerability in any economic activity dedicated to the use of natural resources - which often are irregularly distributed, scarce, etc. Managing this component of vulnerability is the usual business of pastoralism. Another component of vulnerability is that stemming from external forces disturbing the usual working of the pastoral system - encroachment on pastoral land, marginalizing policies, etc. - which undermine the operation of the pastoral production strategies. Following Krätli et al. (2013), we call the former strategic vulnerability and the latter induced vulnerability. As shown in figure 10, there takes place a co-production of the vulnerability of pastoralism between climate and non-climate trends and transformations, which fundamentally mediate the strategic and induced components of vulnerability, respectively. Non-climate transformations make adaptation to climate trends more difficult, and climate trends also affect the ability of pastoral communities to adapt to non-climate transformations.

\section{Conclusions}

Despite the long-standing interest of the research community in the viability of pastoralism, the progress of knowledge on the vulnerability of pastoralism under global environmental change has been remarkable since mid-2000s, with the emergence of climate change as a major policy issue. Illustrative of this vitality is the coexistence of different, often contradictory, lines of thought, picturing pastoralism either as an undesirable anachronism, as an experienced way to cope with scarce and patchy resources in hostile environments, or as high-reliability system specialized in the exploitation of ephemeral resources.

The QCA meta-analysis has proven to be an effective methodology to extract general lessons from the examination of patterns and trends across the literature. In particular, six different pathways of vulnerability arose in the comparison of the case studies, which show the varied circumstances that the diverse pastoral groups are currently coming across in different parts of the world, according to the papers sampled. All through this characterization, four major forces emerged with a determinant influence on the co-production of the vulnerability of pastoralists: (i) the double exposure of pastoralists, which creates pastoral vulnerability to climate and non-climate trends and transformations; (ii) the persistence of unfavorable development policies, fundamentally triggered by a combination of vested interests on pastoral 

adaptation strategies and economic practices; and finally (iv) the multifaceted role of markets.

Consequently, in order to strengthen pastoralism the development of enabling policies and the recognition of pastoral rights and institutions become inescapable. To that end, improving the communication of well-informed narratives on pastoralists, based on the existing scientific evidence, appears as critical: first, highlighting the multiple benefits that this activity provides, such as environmental services, carbon sequestration or efficiency in human-edible protein production; and, second, instead of associating pastoralism with economic strategies of risk-aversion for survival in unfavorable environmental conditions, underlining the specialized nature of pastoralism in exploiting transient resources through highreliability organization. Stopping unfavorable policies aiming at pastoralists is crucial to diminish the induced component of the pastoral vulnerability, which indirectly will also diminish the strategic component of vulnerability, and in turn will enhance the capacity of pastoralism of exploiting non-equilibrium conditions through high-reliability organization in a scenario of increasing changing conditions. Under unpredictable conditions, and specifically when failure is potentially devastating, the reliability of a system becomes a much more desired feature than profitability.

\section{References}

Abu-Rabia, A. (1994) The Negev Bedouin and Livestock Rearing. Berg, Oxford. Circumpolar North. Berghahn Books, Oxford. 426-448. Pastoralism, Drought and Planning: Lessons from Northern Kenya and Elsewhere. Natural Resources Institute, Chatham. p. 104-38. 

north-eastern Ethiopia. Climate change working paper 4. IIED, London. and Pastoral Adaptation in African Savannas. Overseas Development Institute, London. 565.

541 Blackwell, P.J. (2010) East Africa's Pastoralist Emergency: is climate change the straw that breaks the camel's back? Third 542 World Q 31, 1321-1338.

543 Blench, R. (2001) You can't go home again. Pastoralism in the new millennium. Overseas Development Institute, 544 Cambridge.Bradburd, D., 1990. Ambiguous Relations. Smithsonian Institution Press, Washington. Bradley, D. and Grainger, A. (2004) Social resilience as a controlling influence on desertification in Senegal. Land Degrad Dev 15, 451-470. environment in northern Mali. Environ Sci Policy 25, 94-106.

549 Brocklesby, M.A, Hobley, M. and Scott-Villiers, P. (2010) Raising Voice, Securing a Livelihood. IDS Working Paper 340, 550 Institute of Development Studies, Brighton.

551 Burton, I., White, G. and Kates, R. (1978) Environment as Hazard. Oxford Univ. Press, New York.

552 Butt, B. (2011) Coping with Uncertainty and Viability: The Influence of Protected Areas on Pastoral Herding Strategies in 553 East Africa. Hum Ecol 39, 289-307.

554 Catley, A., Leyland, T., Mariner, J.C., Akabwai, D.M.O., Admassu, B., Asfaw, W., Bekele, G. and Hassan, H.S. (2004) Paraveterinary Professionals and the Development of Quality, Self-sustaining Community-based Services. Revue Scientifique et Technique de l'Office Internationale des Epizooties 23, 225-52. 

the Inner Mongolia grazing ecosystems. Nomad People 9, 131-145. of understanding agriculture as performance. NJAS-Wagen J Life Sc 57, 179-185. 74, 307-309. Climate. Environ Manage 50, 929-941. on livestock and forests in northern Mali. Int Forest Rev 13, 123-135. Pasture Uses: A Case Study in the High Atlas Mountains of Marrakech, Morocco. Hum Ecol 38, 351-362.

577 Dong, S., Wen, L., Liu, S., Zhang, X., Lassoie, J.P., Yi, S., Li, X., Li, J. and Li, Y. (2011) Vulnerability of Worldwide Pastoralism to Global Changes and Interdisciplinary Strategies for Sustainable Pastoralism. Ecol Soc 16, 10.

579 Dong, S.K., Wen, L., Zhu, L., Lassoie, J.P., Yan, Z.L., Shrestha, K.K., Pariya, D. and Sharma, E. (2009) Indigenous yak and yakcattle crossbreed management in high altitude areas of northern Nepal: A case study from Rasuwa district. Afr J Agric Res 10, 957-967. 
585 Dyson-Hudson, R. and McCabe, J.T. (1985) South Turkana Nomadism: Coping with an Unpredictably Varying Environment. HRAFLEX, New Haven. Pastorale et Societe. Cambridge University Press, Cambridge. Environ Manage 43, 817-835. countries: A meta-analysis. J Environ Manage 92, 1938-1949. Oxford University Press, Oxford. Mongolia. J Appl Ecol 36, 871-885. Application to Natural Resource Management and Adaptation. Hum Ecol 40, 287-300. exploratory study in los Valles Occidentales of Aragón. Pirineos. Revista de Ecología de Montaña 167, 143-163. Genova, R.C., Girma, B., Kissel, E.S., Levy, A.N., MacCracken, S., Mastrandrea, P.R. and White, L.L. (eds.) (2014) Climate 604 Change 2014: Impacts, Adaptation and Vulnerability. Part A: Global and Sectoral Aspects. Contribution of Working Group II to the Fifth Assessment Report of the Intergovernmental Panel on Climate change. Cambridge University Press, Cambridge and New York. 22048. 

FAO, Rome. climate change in dryland livelihood systems: conceptual challenges and interdisciplinary solutions. Ecol Soc 16, 3. $14,269-286$.

Fratkin, E. (1997) Pastoralism: governance and development issues. Annu Rev Anthropol 26,235-61

Fratkin, E. and Mearns, R. (2003) Sustainability and pastoral livelihoods: lessons from East African Maasai and Mongolia. Hum Organ 62, 112-22.

Freier, K.P., Bruggemann, R., Scheffran, J., Finskh, M. and Schneider, U.A. (2012) Assessing the predictability of future livelihood strategies of pastoralists in semi-arid Morocco under climate change. Technol Forecast Soc 79, 371-382. Pastoralists: Challenges in Enhancing Local Adaptation Through Policy Support. Environ Manage 50, 607-621. reindeer herding Sami in Sweden. Glob Health Action 4, 8417. social science and remote sensing. Climate Res 19, 161-172. Ethiopia. Indian J Tradit Know 11, 573-579. drought in fragmented landscapes. Glob Environ Chang 23, 588-597. 
636 Harris, R.B. (2010) Rangeland degradation on the Qinghai-Tibetan plateau: A review of the evidence of its magnitude and causes. J Arid Environ 74, 1-12.

638 Hausner, V.H., Fauchald, P., Tveraa, T., Pedersen, E., Jernsletten, J.L., Ulvevadet, B., Ims, R.A., Yoccoz, N.G. and Bråthen, 639 K.A. (2011) The Ghost of Development Past: the Impact of Economic Security Policies on Saami Pastoral Ecosystems. Ecol 640 Soc 16,4

641 Haynes, M.A. and Yang, Y. (2013) Adapting to change: transitions in traditional rangeland management of Tibetan yak 642 herders in northwest Yunnan. Environ Dev Sustain 15, 1065-1077.

643 Hinkel, J. (2011) Indicators of vulnerability and adaptive capacity: towards a clarification of the science-policy interface. 644 Glob Environ Chang 21, 198-208.

645 Hofmann, M.E., Hinkel, J. and Wrobel, M. (2011) Classifying knowledge on climate change impacts, adaptation, and 646 vulnerability in Europe for informing adaptation research and decision-making: A conceptual meta-analysis. Glob Environ 647 Chang 21, 1106-1116.

648 Hou, X.Y., Han, Y. and Li, F.Y. (2012) The perception and adaptation of herdsmen to climate change and climate variability 649 in the desert steppe region of northern China. Rangeland J 34, 349-357.

650 Ifejika Speranza, C. (2010) Drought Coping and Adaptation Strategies: Understanding Adaptations to Climate Change in 651 Agro-pastoral Livestock Production in Makueni District, Kenya. Europ J Devel Res 22, 623-642.

652 Ingram, K.T., Roncoli, M.C. and Kirshen, P.H. (2002) Opportunities and constraints for farmers of west Africa to use seasonal precipitation forecasts with Burkina Faso as a case study. Agr Syst 74, 331-349.

654 Ionescu, C., Klein, R.J.T., Hinkel, J., Kavi Kumar, K.S. and Klein, R. (2009) Towards a formal framework of vulnerability to 655 climate change. Environ Model Assess 14, 1-16.

656 Janes, C.R. (2010) Failed Development and Vulnerability to Climate Change in Central Asia: Implications for Food Security 657 and Health. Asia Pac J Public Health 22, 236S-245S.

658 Jianzhong, Y., Yingying, W.U. and Yili, Z. (2011) Adaptation strategies to pasture degradation: Gap between government and local nomads in the eastern Tibetan Plateau. J Geogr Sci 21, 1112-1122. 

Peoples 3, 94-105. change. Environ Sci Policy 12, 427-37. Jónsson, G. (2010) The Environmental Factor in Migration Dynamics-A Review of African Case Studies. Internation Migration Institute, Working Paper 21. IMI, Oxford. http://www.imi.ox.ac.uk/pdfs/imi-working-papers/wp21-jonsson. change. In: Kasperson, J.X., Kasperson, R.E. (eds.), Social Contours of Risk. Vol. II: Risk Analysis Corporations and the Globalization of Risk. Earthscan, London, pp. 245-285. Pamirs. Hum Ecol 37, 677-690. determining local vulnerability and adaptive capacity. Mitig Adapt Strat GI 14, 185-201. Xiantiaozhan, pp. 1-23. Khazanov, A.M. (1994) Nomads and the Outside World. University of Wisconsin Press, Madison. Konstantinov, Y. (2010) Socioeconomic Life of Climate Change: Extensivity in Reindeer Husbandry in Relation to Synergies between Social and Climate Change (Kola Peninsula). Acta Borealia: A Nordic Journal of Circumpolar Societies 27, 44-65. 

climate change. Animal Frontiers 3, 42-50.

Krätli, S. and Shareika, N. (2010) Living Off Uncertainty: The Intelligent Animal Production of Dryland Pastoralists. Eur J Dev Res 22, 605-622.

Kyalo Willy, D. and Chiuri, W. (2010) New Common Ground in Pastoral and Settled Agricultural Communities in Kenya: Renegotiated Institutions and the Gender Implications. Eur J Dev Res 22, 733-750.

691 Lamprey, H.F. (1983) Pastoralism yesterday and today: the overgrazing problem. In: Bourliere, F. (ed.), Tropical Savannas. Elsevier Science, Amsterdam, pp. 643-666. and privatization of resources use in rural communities of south-western Niger. Agr Syst 83, 251-276. ritual relationship with the natural environment. Polar Res 49, 260-271. Mongolia: Tragic Feedbacks. Ecol Soc 16, 1. points in the rangelands of Northern Senegal based on NOAA AVHRR data. Geografisk Tidsskrift (Danish Journal of Geography) 103, 1-15. D.C. (eds.), Population and Environment: Rethinking the Debate. Boulder, Westview, pp. 209-251. Management among East African Herders. Dev Change 32, 401-433. Development Studies, Brighton. 

Mongolia. Glob Environ Chang 20, 162-176. Recession: Evaluating Hydrologic Changes and Livelihood Vulnerability in the Cordillera Blanca, Peru. Ann Assoc Am Geogr 100, 794-805.

Marx, E. (1977) The tribe as a unit of subsistence: nomadic pastoralism in the Middle East. Am Anthropol 79, 343-363.

McCabe, J.T. (1990) Turkana pastoralism: a case against the tragedy of the commons. Hum Ecol 18, 81-103.

McDowell, J.Z. and Hess, J.J. (2012) Accessing adaptation: Multiple stressors on livelihoods in the Bolivian highlands under a changing climate. Glob Environ Chang 22, 342-352.

McPeak, J. and Little, P.D. (2005) Cursed if you do, cursed if you don't: the contradictory processes of pastoral Consequences of Pastoral Sedentarization in Marsabit District, Kenya. Kluwer Academic Publishers, New York, pp. 87-104. Group International, London.

Mogotsi, K., Nyangito, M.M. and Nyariki, D.M. (2012) Vulnerability of rural agro-pastoral households to drought in semiarid Botswana. Livestock Res Rural Dev 24, 1-8. University of Greenwich, London. Geol Sin-Engl 83, 1017-1023. Kenya's Drylands. Journal of Environmental Science and Technology 4, 403-410. 

Sustainable Development \& World Ecology 20, 123-133.

Nettier, B., Dobremez, L., Coussy, J.L. and Romagny, T. (2010) Attitudes of livestock farmers and sensitivity of livestock farming systems to drought conditions in the French Alps. Rev Geogr Alp 98, 4.

739

Ng'ang'a, S.K., Jeannette, V., Notenbaert, A., Moyo, S. and Herrero, M. (2011) Household livelihood strategies and livestock benefits dependence in Gaza province of Mozambique. Afr J Agric Res 6, 560-572.

741 Nori, M. (2007) Mobile Livelihoods, Patchy Resources \& Shifting Rights: Approaching Pastoral Territories. International Land Coalition, Rome. change. IIED, issue paper 148. vulnerability index for empirically testing measures of adaptive capacity and vulnerability. Reg Environ Change 13, 459-470. Kenya. Nomad People 17, 66-86.

Orlove, B.S. (1982) Native Andean pastoralists: traditional adaptations and recent changes. In: Salzman, P.C. (ed.), Contemporary nomadic and pastoral peoples: Africa and Latin America. Williamsburg, Virginia: College of William and Mary, pp. 95-136 and ecosystem-based adaptation in Kenya Masailand. Int J of Cl Chan Strat and Man 5, 198-214.

Ouma, R., Mude, A. and van de Steeg, J. (2011) Dealing with climate-related risks: some pioneering ideas for enhanced pastoral risk management in Africa. Experimental Agriculture 47, 375-393.

Owuor, B., Mauta, W. and Eriksen, S. (2011) Sustainable adaptation and human security: Interactions between pastoral and agropastoral groups in dryland Kenya. Climate and Development 3, 42-58. 

Andes. Hum Ecol 36, 535-551. socio-economic change on the Seward Peninsula, Alaska. Polar Res 28, 71-88. Reindeer Herding: The Nation-State as Problem and Solution. Working Papers in Technology Governance and Economic Dynamics no. 16. The other canon foundation, Norway; Tallinn University of Technology, Tallinn. security. VSF-Belgium, SIVTRO, AVSF and VSF-CZ, Barcelona. $387-421$. Roe, E. and Schulman, P.R. (2008) High Reliability Management. Operating on the Edge. Stanford University Press, Stanford. Environ Chang 18, 18-25. Salzman, P.C. (1974) Tribal chiefs as middlemen: the politics of encapsulation in the Middle East. Anthropol Q 47, 203-210. Sandford, S. (1983) Management of Pastoral Development in the Third World. John Wiley, Chichester. www.futureagricultures.org/pdf\%20files/Sandford_thesis.pdf. (last accessed on 20-4-2015) Directions in Pastoral Development in Africa. Intermediate Technology Publications, London, pp. 1-36. 

Zinder Regions of Niger. Ecol Soc 16, 1. Simpson, J.R. and Evangelou, P. (eds.) (1984) Livestock Development in Subsaharan Africa: Constraints, Prospects, Policy. Boulder, Westview.

789 Smucker, T. and Wisner, B. (2008) Changing household responses to drought in Tharaka, Kenya: vulnerability, persistence and challenge. Disasters 32, 190-215.

791 Sneath, D. (2012) The 'age of the market' and the regime of debt: the role of credit in the transformation of pastoral Mongolia. Social Anthropology/Anthropologie Sociale 20, 458-473.

Steen, E. (1994) Drylands of the Third World: potential for future development. Ambio 23, 458-460.

794 Stenning, D.J. (1959) Savannah Nomads. Oxford University Press, London.

795 Sternberg, T., Middleton, N. and Thomas, D. (2009) Pressurized pastoralism in South Gobi, Mongolia: what is the role of drought? T I Brit Geogr 34, 364-377.

797 Sulieman, H.M. and Elagib, N.A. (2012) Implications of climate, land-use and land-cover changes for pastoralism in eastern Sudan. J Arid Environ 85, 132-141. Sullivan, S. and Rohde, R. (2002) On non-equilibrium in arid and semi-arid grazing systems. J Biogeogr 29, 1595-1618. Swift, J. (1996) Desertification: Narratives, Winners and Losers. In: Leach, M., Mearns, R., (eds.), The Lie of the Land: Challenging Received Wisdom on the African Environment. International African Institute in association with James Currey Ltd, Oxford. Thébaud, B. and Batterbury, S. (2001) Sahel pastoralists: opportunism, struggle, conflict and negotiation. A case study from Niger. Glob Environ Chang 11, 69-78. Troll, C. (1931) Die geographische Grundlage der Andinen Kulturen und des Inkareiches. Ibero-Amerikanisches Archiv 5, 137. Troll, C. (1966) Ökologische Landschaftsforschung und vergleichende Hochgebirgsforschung. Wiesbaden, Steiner. Turner, M.D. (1999) The role of social networks, indefinite boundaries and political bargaining in maintaining the ecological and economic resilience of the transhumance systems of Sudan-Sahelian West Africa. In: Niamir-Fuller, M. (ed.), Managing Mobility in African Rangelands. FAO, Beijer International Institute of Ecological Economics, London, pp. 97-123. 
811 Turner, B.L. II, Kasperson, R.E., Matson, P.A., McCarthy, J.J., Corell, R.W., Christensen, L., Eckley, N., Kasperson, J.X., Luers,

812 A., Martello, M.L., Polsky, C., Pulsipher, A. and Schiller, A. (2003) A framework for vulnerability analysis in sustainability 813 science. Proc Natl Acad Sci 100, 8074-8079.

814 Tyler, N.J.C., Turi, J.M., Sundset, M.A., Strøm Bull, K., Sara, M.N., Reinert, E., Oskal, N., Nellemann, C., McCarthy, J.J., 815 Mathiesen, S.D., Martello, M.L., Magga, O.H., Hovelsrud, G.K., Hanssen-Bauer, I., Eira, N.I., Eira, I.M.G. and Corell, R.W. 816 (2007) Saami reindeer pastoralism under climate change: Applying a generalized framework for vulnerability studies to a 817 sub-arctic social-ecological systems. Glob Environ Chang 17, 191-206.

818 Valdivia, C., Seth, A., Gilles, J.L., García, M., Jiménez, E., Cusicanqui, J., Navía, F. and Yucra, E. (2010) Adapting to climate 819 change in Andean ecosystems: landscape, capitals, and perceptions shaping rural livelihood strategies and linking 820 knowledge systems. Ann Assoc Am Geogr 100, 818-834.

821 Verzijl, A. and Guerrero Quispe, S. (2013) The System Nobody Sees: Irrigated Wetland Management and Alpaca Herding in the Peruvian Andes. Mt Res Dev 33, 280-293. van Vliet, N., Mertz, O., Heinimann, A., Langanke, T., Pascual, U., Schmook, B., Adams, C., Schmidt-Vogt, D., Messerli, P., Leisz, S., Castella, J.C., Jørgensen, L., Birch-Thomsen, T., Hett, C., Bech-Bruun, T., Ickowitz, A., Chi Vu, K., Yasuyuki, K., Fox, J., Padoch, C., Dressler, W. and Ziegler, A.D. (2012) Trends, drivers and impacts of changes in swidden cultivation in tropical forest-agriculture frontiers: A global assessment. Glob Environ Chang 22, 418-429.

827 Vuojala-Magga, T., Turunen, M., Ryyppö, T. and Tennberg, M. (2011) Resonance Strategies of Sámi Reindeer Herders in Northernmost Finland during Climatically Extreme Years. Arctic 64, 227-241. 3, 250-262. Wang, X. and Zhang, Q. (2012) Climate variability, change of land use and vulnerability in pastoral society: a case from Inner Mongolia. Nomad People 16, 68-87. among Tibetan Nomads: A Case from Gangga Township, Dingri County, Tibetan Autonomous Region of China. EcoHealth 5, 104-114. 
837 Yosef, T., Mengistu, U., Solomon, A., Mohammed, Y.K. and Kefelegn, K. (2013) Camel and cattle population dynamics and 838 livelihood diversification as a response to climate change in pastoral areas of Ethiopia. Livest Res Rural Dev 25, 9.

839 Young, O.R., Lambin, E.F., Alcock, F., Haberl, H., Karlsson, S.I., McConnell, W.J., Myint, T., Pahl-Wostl, C., Polsky, C., 840 Ramakrishnan, P.S., Schroeder, H., Scouvart, M. and Verburg, P.H. (2006) A Portfolio Approach to Analyzing Complex 841 Human-Environment Interactions: Institutions and Land Change. Ecol Soc 11, 31. America. Climatic Change 78, 63-102. 
863 Table 1. Pathways of vulnerability in pastoral regions.

864 Sources: 1, Goldman and Riosmena (2013); 2, Djoudi et al. (2013); 3, Zgang et al. (2013); 4, Joshi et al. (2013); 5, Osano et al. (2013); 6 , 865 Naess (2013); 7, Notenbaert et al. (2013); 8, Brockhaus et al. (2013); 9, Haynes and Yang (2013); 10, Hou et al. (2012); 11, Sneath (2012); 866 12, Dieye and Roy (2012); 13, Fu et al. (2012); 14, Mogotsi et al. (2012); 15, Sulieman and Elagib (2012); 16, Wang and Zhang (2012); 17, 867 Freier et al. (2012); 18, Fernández-Giménez and Fillat (2012a); 19, Jianzhong et al. (2011); 20, Li and Huntsinger (2011); 21, Djoudi and 868 Brockhaus (2011); 22, Butt (2011); 23, Ouma et al. (2011); 24, Mwang'ombe et al. (2011); 25, Ng'ang'a et al. (2011); 26, Crane et al. (2011); 869 27, Owuor et al. (2011); 28, Blackwell (2010); 29, Ifejika Speranza (2010); 30, Crane (2010); 31, Wang and Zhang (2010); 32, Mark et al. 870 (2010); 33, Dougill et al. (2010); 34, Hadfdan Aase et al. (2009); 35, Marin (2010); 36, Forbes et al. (2009); 37, Dong et al. (2009); 38, 871 Eriksen and Lind (2009); 39, Eriksen and Lind (2009); 40, Rattenbury et al. (2009); 41, Keskitalo (2009); 42, Postigo et al. (2008); 43, Tyler et 872 al. (2007); 44, Young and Lipton (2006); 45, Christensen et al. (2005); 46, Ingram et al. (2002); 47, Galvin et al. (2001); 48, Beyene (2010); 873 49, Dominguez et al. (2010); 50, Kassam (2009); 51, Sternberg et al. (2009); 52, Muho et al. (2009); 53, La Rovere et al. (2005); 54, Little et 874 al. (2001); 55, Kyalo Willy and Chiuri (2010); 56, Biazin and Sterk (2013); 57, Fernández-Giménez and Fillat (2012b); 58, Vuojala-Magga et 875 al. (2011); 59, Cossins and Upton (1988); 60, Sendzimir et al. (2011); 61, Astigarraga and Ingrand (2011); 62, Hausner et al. (2011); 63, 876 Furberg et al. (2011); 64, Janes (2010); 65, Nettier et al. (2010); 66, Banerji and Basu (2010); 67, Smucker and Wisner (2008); 68, Xu et al. 877 (2008); 69, Gebresenbet and Kefale (2012); 70, Konstantinov (2010); 71, Pantuliano (2010); 72, Verzijl and Guerrero Quispe (2013); 73, 878 Yosef et al. (2013); 74, Lavrillier (2013); 75, Ole Seno and Tome (2013).

Table 2. Commonalities and specificities of the diverse pathways of vulnerability of pastoralism identified. 
Fig. 1. World pastoral regions.

Fig. 2. Number of case studies recorded per country.

Note that some case studies transcend national boundaries.

Fig. 3. The Encroachment pathway of vulnerability.

Note: The three dimensions of vulnerability are represented in the figure. Exposure is illustrated by climate trends and non-climate transformations being experienced by the pastoral groups. Sensitivity is illustrated by impacts on pastoral resources and pastoral land conversions. Adaptation is illustrated by the adaptation strategies described in each case. The bar chart referring to climate trends shows the percentage of case studies comprising this pathway that report each of the nine trends described. Only those more frequent are labelled. The pie chart of non-climate transformations shows the percentage of them belonging to each of the following subgroups of drivers: policy and institutional, sociocultural, economic, demographic and biophysical. The number of non-climate transformations in each case is in brackets. Sensitivity is represented by impacts on pastoral resources and pastoral land conversions. The bar chart of the former illustrates the percentage of case studies where each of the eighteen most reported impacts were described. Negative percentage indicates decreasing effects, while positive percentage indicates increasing effects. Only those most common are labelled. The bar chart of pastoral land conversions shows the percentage of case studies where the nine most described land conversions were reported. Negative percentage indicates the detrimental nature of this impact for pastoralists, while positive percentage indicates the opposite. Only those most common land conversions are labelled. Concerning adaptation, the pie chart of adaptation strategies shows the percentage of them that belongs to the following broad adaption lines: mobility, diversification, communal pooling, market exchange, intensification, storage, available in Appendixes A, B, C and D.

$914 \quad$ Fig. 4. The Re-greening pathway of vulnerability.

915 See note to Fig. 3.

916 Fig. 5. The Customary pathway of vulnerability. See note to Fig. 3.

918 Fig. 6. The Polarization pathway of vulnerability. See note to Fig. 3.

Fig. 7. The Communal pathway of vulnerability. 
922 Fig. 8. The No-alternative pathway of vulnerability.

923 See note to Fig. 3.

924 Fig. 9. Performance in the main components of the vulnerability of pastoralism of the diverse pathways.

925 The scores of the figures are percentages, going from 0 in the centers to 100 in the extremes. Out of the total of items of the five

926 components of the three dimensions of vulnerability reported considering all case studies of our sample, the percentage indicates the

927 number of them that were reported in each pathway of vulnerability. The average scores are in black, while the scores specific for each

928 pathway are in grey. This figure is based on the data available in Appendixes A, B and C.

929 Fig. 10. Co-production of the vulnerability of pastoralism. 


\begin{tabular}{|c|c|c|c|c|c|c|}
\hline & ENCROACHMENT & RE-GREENING & CUSTOMARY & POLARIZATION & COMMUNAL & NO-ALTERNATIVE \\
\hline Northern Africa & 17,49 & & & & & \\
\hline Eastern Africa & $\begin{array}{l}1,5,22,27,28,29,38 \\
39,47,48,54,55,56 \\
67,69,71,75\end{array}$ & & $23,24,59$ & & & $15,52,73$ \\
\hline Western Africa & $30,46,53$ & $2,8,21$ & 26 & 60 & & 12 \\
\hline Southern Africa & 33 & & $7,14,25$ & & & \\
\hline Himalaya-Pamir & 68 & & 50,66 & 34 & & $4,6,9,13,19,37$ \\
\hline Andes & & & 32 & & $42,44,72$ & \\
\hline Arctic & & & & & 36,74 & $40,41,43,58,62,63,70$ \\
\hline European mountains & & & & $18,57,61,65$ & & \\
\hline
\end{tabular}




\begin{tabular}{|c|c|c|c|c|c|c|}
\hline & $\begin{array}{c}\frac{\text { ENCROACHMENT }}{(40 \%)} \\
\end{array}$ & $\frac{\text { RE-GREENING }}{(4 \%)}$ & $\frac{\text { CUSTOMARY }}{(13.3 \%)}$ & $\frac{\text { POLARIZATION }}{(8 \%)}$ & $\frac{\text { COMMUNAL }}{(6.7 \%)}$ & $\frac{\text { NO-ALTERNATIVE }}{(28 \%)}$ \\
\hline $\begin{array}{l}\text { EXPOSURE } \\
\text { (climate trends) }\end{array}$ & Seasonality, drought & $\begin{array}{l}\text { Seasonality, drought, } \\
\text { wind }\end{array}$ & $\begin{array}{l}\text { Seasonality, drought, } \\
\text { flood }\end{array}$ & $\begin{array}{l}\text { Seasonality, drought, } \\
\text { rising temperatures }\end{array}$ & $\begin{array}{l}\begin{array}{l}\text { Seasonality, rising } \\
\text { temperatures, glacier } \\
\text { retreat }\end{array} \\
\end{array}$ & $\begin{array}{l}\text { Seasonality, rising } \\
\text { temperatures }\end{array}$ \\
\hline $\begin{array}{l}\text { EXPOSURE } \\
\text { (non-climate } \\
\text { transformation) }\end{array}$ & $\begin{array}{l}\text { Policy: land, } \\
\text { marginalizing, } \\
\text { sedentarization. } \\
\text { Social: changes in } \\
\text { traditional institutions, } \\
\text { conflict. } \\
\text { Economic: market, } \\
\text { agriculture. } \\
\text { Demographic: } \\
\text { population growth, } \\
\text { emigration. }\end{array}$ & $\begin{array}{l}\text { Policy: land, } \\
\text { marginalizing, aid, } \\
\text { sedentarization, } \\
\text { extension, centralized } \\
\text { services. } \\
\text { Social: changes in } \\
\text { traditional institutions, } \\
\text { conflict. } \\
\text { Economic: agriculture, } \\
\text { infrastructure. } \\
\text { Demographic: } \\
\text { emigration. } \\
\text { Biophysical: drying lake, } \\
\text { invasive species, } \\
\text { afforestation }\end{array}$ & $\begin{array}{l}\text { Policy: marginalizing. } \\
\text { Demographic: } \\
\text { population growth. }\end{array}$ & $\begin{array}{l}\text { Policy: land. } \\
\text { Social: less for conflicts } \\
\text { Economic: market, } \\
\text { tourism. } \\
\text { Biophysical: } \\
\text { afforestation. }\end{array}$ & $\begin{array}{l}\text { Policy: land, } \\
\text { sedentarization } \\
\text { Social: changes in } \\
\text { traditional institutions, } \\
\text { conflict. } \\
\text { Economic: market, mining, } \\
\text { urbanization, } \\
\text { infrastructure. } \\
\text { Demographic: population } \\
\text { growth, emigration. } \\
\text { Biophysical: extinction of } \\
\text { species, expansion of } \\
\text { damaging species. }\end{array}$ & $\begin{array}{l}\text { Policy: land, } \\
\text { marginalizing. } \\
\text { Social: changes in } \\
\text { traditional institutions. } \\
\text { Economic: market. }\end{array}$ \\
\hline $\begin{array}{l}\text { SENSITIVITY } \\
\text { (pastoral } \\
\text { resources) }\end{array}$ & $\begin{array}{l}\text { Decreasing: rangeland, } \\
\text { mobility, customary } \\
\text { practices, livestock } \\
\text { number, productivity, } \\
\text { water, food security, } \\
\text { social justice, labor, } \\
\text { social network. } \\
\text { Increasing: market, } \\
\text { insecurity. }\end{array}$ & $\begin{array}{l}\text { Decreasing: rangeland, } \\
\text { mobility, customary } \\
\text { practices, livestock } \\
\text { number, water, food } \\
\text { security, social justice, } \\
\text { labor, social network, } \\
\text { soil, humane health. } \\
\text { Increasing: insecurity, } \\
\text { forest. }\end{array}$ & $\begin{array}{l}\text { Decreasing: rangeland, } \\
\text { livestock number, } \\
\text { productivity, water, } \\
\text { food security, social } \\
\text { justice, income, } \\
\text { humane health. }\end{array}$ & $\begin{array}{l}\text { Decreasing: livestock } \\
\text { number, water, } \\
\text { livestock health and } \\
\text { conflict. } \\
\text { ncreasing: market, } \\
\text { forest. }\end{array}$ & $\begin{array}{l}\text { Decreasing: rangeland, } \\
\text { mobility, customary } \\
\text { practices, water, social } \\
\text { justice, social network, } \\
\text { forest. } \\
\text { Increasing: market, } \\
\text { insecurity, labor, } \\
\text { demography. }\end{array}$ & $\begin{array}{l}\text { Decreasing: rangeland, } \\
\text { mobility, customary } \\
\text { practices, livestock } \\
\text { number, productivity, } \\
\text { income. } \\
\text { Increasing: overgrazing. }\end{array}$ \\
\hline $\begin{array}{l}\text { SENSITIVITY } \\
\text { (land } \\
\text { conversions) }\end{array}$ & $\begin{array}{l}\text { Detrimental: degraded } \\
\text { land, privatization, } \\
\text { agriculture. }\end{array}$ & $\begin{array}{l}\text { Detrimental: degraded } \\
\text { land, privatization, } \\
\text { Irrigated agriculture. } \\
\text { Favorable: forest. }\end{array}$ & $\begin{array}{l}\text { Detrimental: degraded } \\
\text { land. } \\
\text { Favorable: irrigated } \\
\text { agriculture. }\end{array}$ & $\begin{array}{l}\text { Detrimental: abandoned } \\
\text { pastures. }\end{array}$ & $\begin{array}{l}\text { Detrimental: mining, } \\
\text { infrastructures. } \\
\text { Favorable: irrigated } \\
\text { pasture. }\end{array}$ & $\begin{array}{l}\text { Detrimental: degraded } \\
\text { land. }\end{array}$ \\
\hline ADAPTATION & $\begin{array}{l}\text { Mobility: herd, varying } \\
\text { grazing patterns, } \\
\text { household, } \\
\text { remittances. } \\
\text { Diversification: labor, } \\
\text { farm, livestock. } \\
\text { Communal pooling: } \\
\text { reciprocity, herding, } \\
\text { livestock loans. } \\
\text { Market: improved } \\
\text { market access, input } \\
\text { purchase, new product } \\
\text { sale. } \\
\text { Intensification: pasture } \\
\text { enclosure, } \\
\text { sedentarization. } \\
\text { Storage: herd, feed. } \\
\text { Extensification: leaving } \\
\text { pastoralism. }\end{array}$ & $\begin{array}{l}\text { Mobility: herd, varying } \\
\text { grazing patterns, } \\
\text { household, } \\
\text { remittances. } \\
\text { Diversification: labor, } \\
\text { farm, livestock, herd } \\
\text { strategy, changes in } \\
\text { species, skills. } \\
\text { Communal pooling: } \\
\text { conflict resolution. } \\
\text { Market: new product } \\
\text { sale. } \\
\text { Intensification: } \\
\text { increased input use, } \\
\text { sedentarization. } \\
\text { Storage: herd, } \\
\text { restocking. }\end{array}$ & $\begin{array}{l}\text { Mobility: herd, } \\
\text { remittances. } \\
\text { Diversification: labor, } \\
\text { farm, livestock. } \\
\text { Communal pooling: } \\
\text { reciprocity, } \\
\text { infrastructure, children } \\
\text { labor. } \\
\text { Market: improved } \\
\text { market access, new } \\
\text { product sale. } \\
\text { Storage: water. }\end{array}$ & $\begin{array}{l}\text { Mobility: herd, varying } \\
\text { grazing patterns. } \\
\text { piversification: labor, } \\
\text { farm, livestock, skills, } \\
\text { changes in species. } \\
\text { Market: improved } \\
\text { market access, input } \\
\text { purchase, new product } \\
\text { sale. } \\
\text { Intensification: feed } \\
\text { cropping, stall feed, } \\
\text { leaving distant pasture } \\
\text { Storage: feed. } \\
\text { Extensification: leaving } \\
\text { pastoralism, land } \\
\text { increase, shifting from } \\
\text { feed crop to pasture. }\end{array}$ & $\begin{array}{l}\text { Mobility: herd, varying } \\
\text { grazing patterns, } \\
\text { household, remittances. } \\
\text { Diversification: labor, farm, } \\
\text { livestock. } \\
\text { Communal pooling: } \\
\text { reciprocity, herding, } \\
\text { infrastructure, labor } \\
\text { exchange, bartering, } \\
\text { conflict resolution. } \\
\text { Market: improved market } \\
\text { access, new product sale. } \\
\text { Intensification: } \\
\text { sedentarization. } \\
\text { Storage: water. } \\
\text { Extensification: leaving } \\
\text { pastoralism. }\end{array}$ & $\begin{array}{l}\text { Mobility: herd, varying } \\
\text { grazing patterns. } \\
\text { Diversification: labor. } \\
\text { Communal pooling: } \\
\text { herding. } \\
\text { Market: input purchase. } \\
\text { Intensification: } \\
\text { increased input use. }\end{array}$ \\
\hline REGION & $\begin{array}{l}\text { Africa, mainly Eastern } \\
\text { Africa, and Mongolia }\end{array}$ & Western Africa & $\begin{array}{l}\text { Eastern and Southern } \\
\text { Africa, and Himalaya- } \\
\text { Pamir }\end{array}$ & $\begin{array}{l}\text { European mountains } \\
\text { principally }\end{array}$ & Andes and Arctic & $\begin{array}{l}\text { Arctic and Himalaya- } \\
\text { Pamir, mostly, and } \\
\text { Mongolia }\end{array}$ \\
\hline № households & General decrease & Total decrease & Marginal increase & General decrease & General increase & General decrease \\
\hline
\end{tabular}




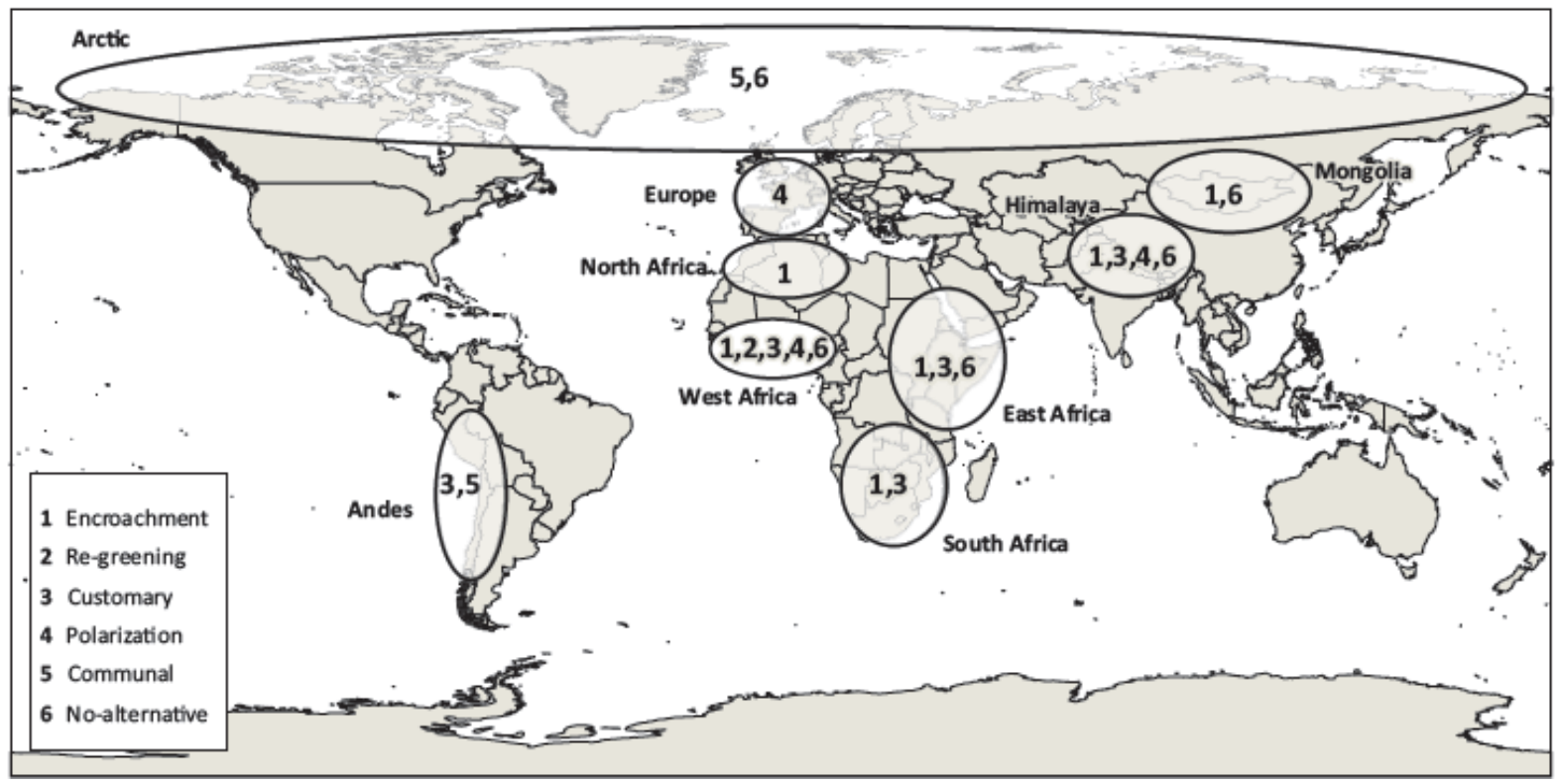


Figure2

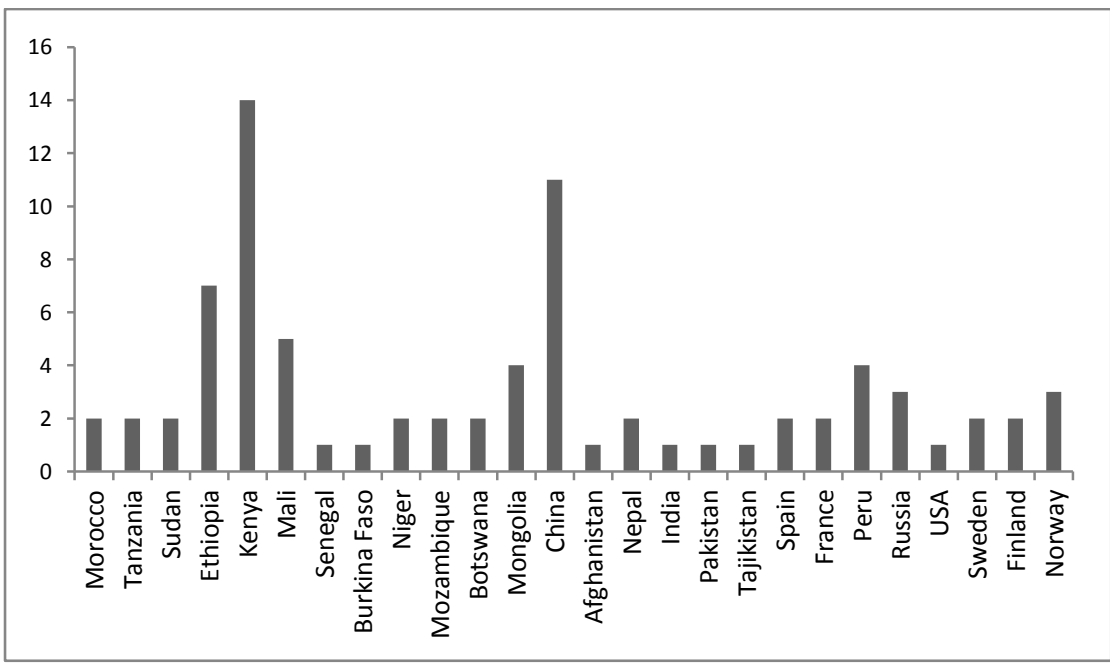




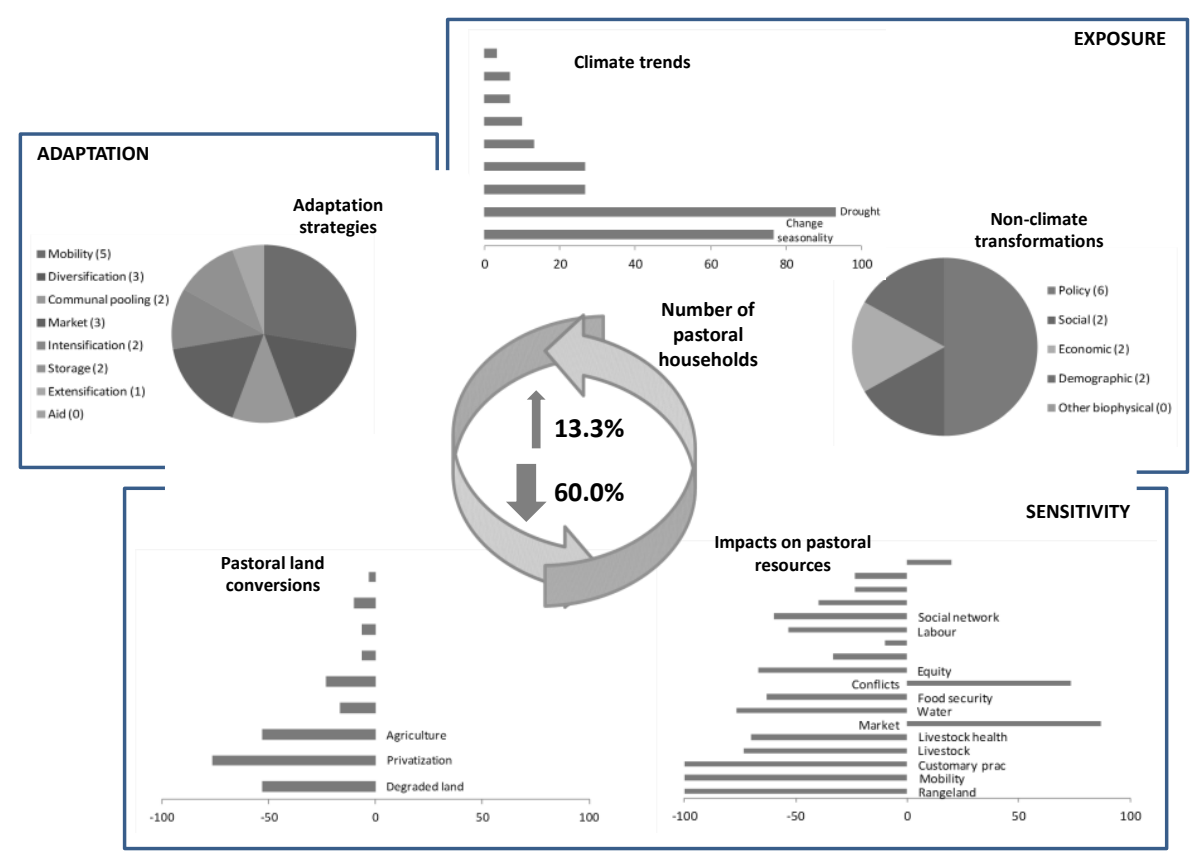




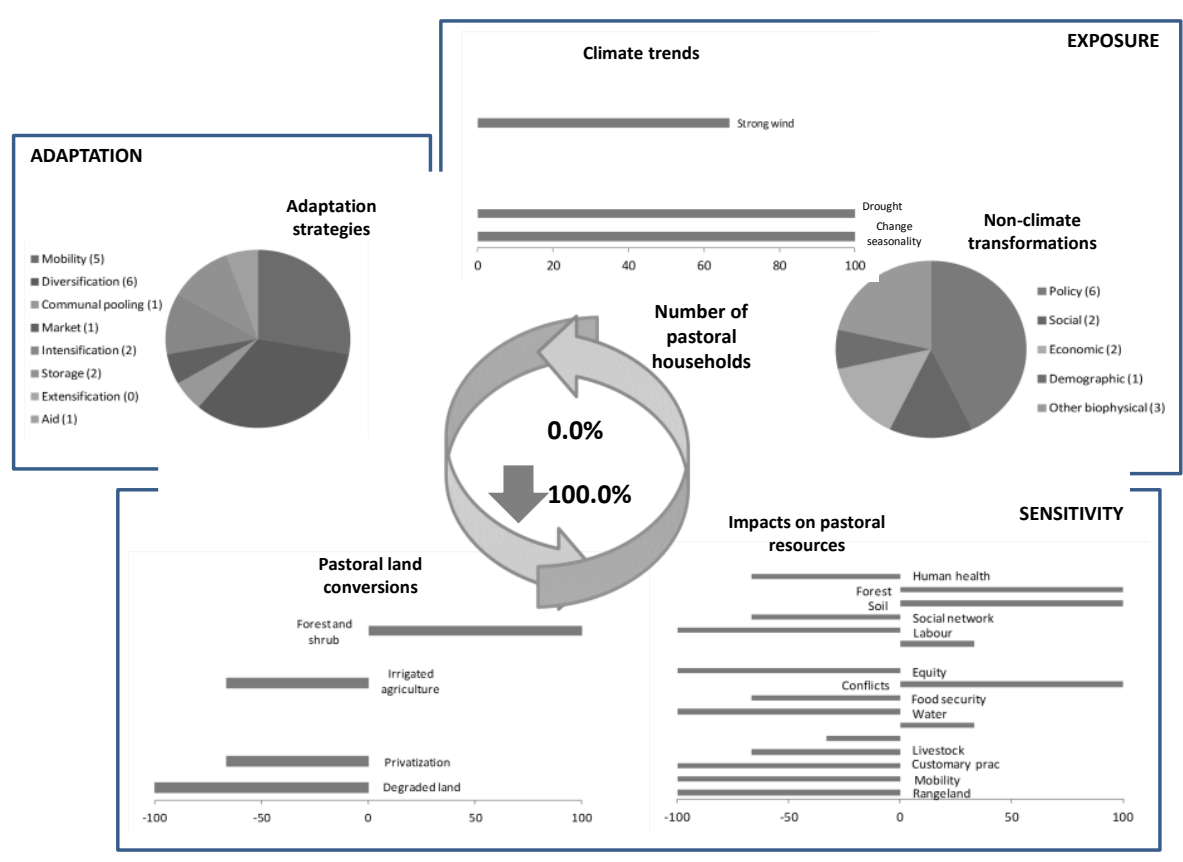




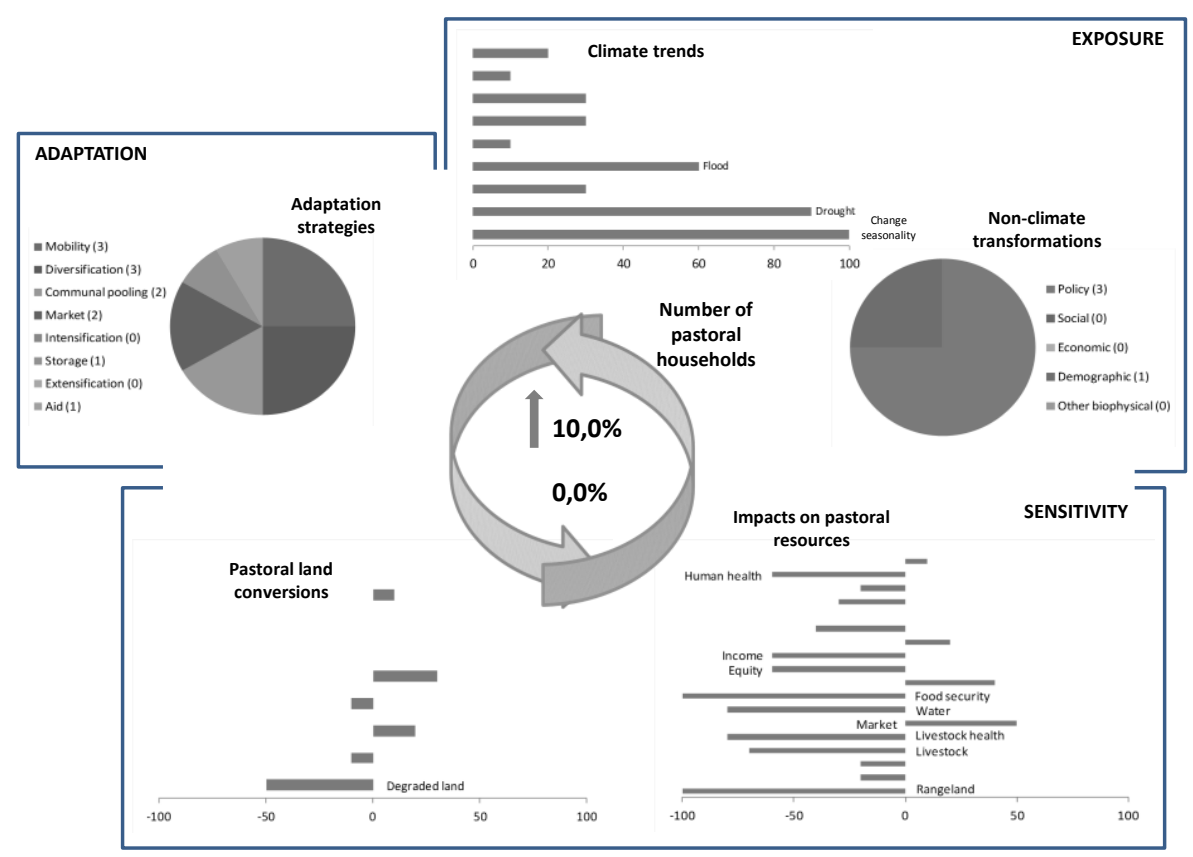




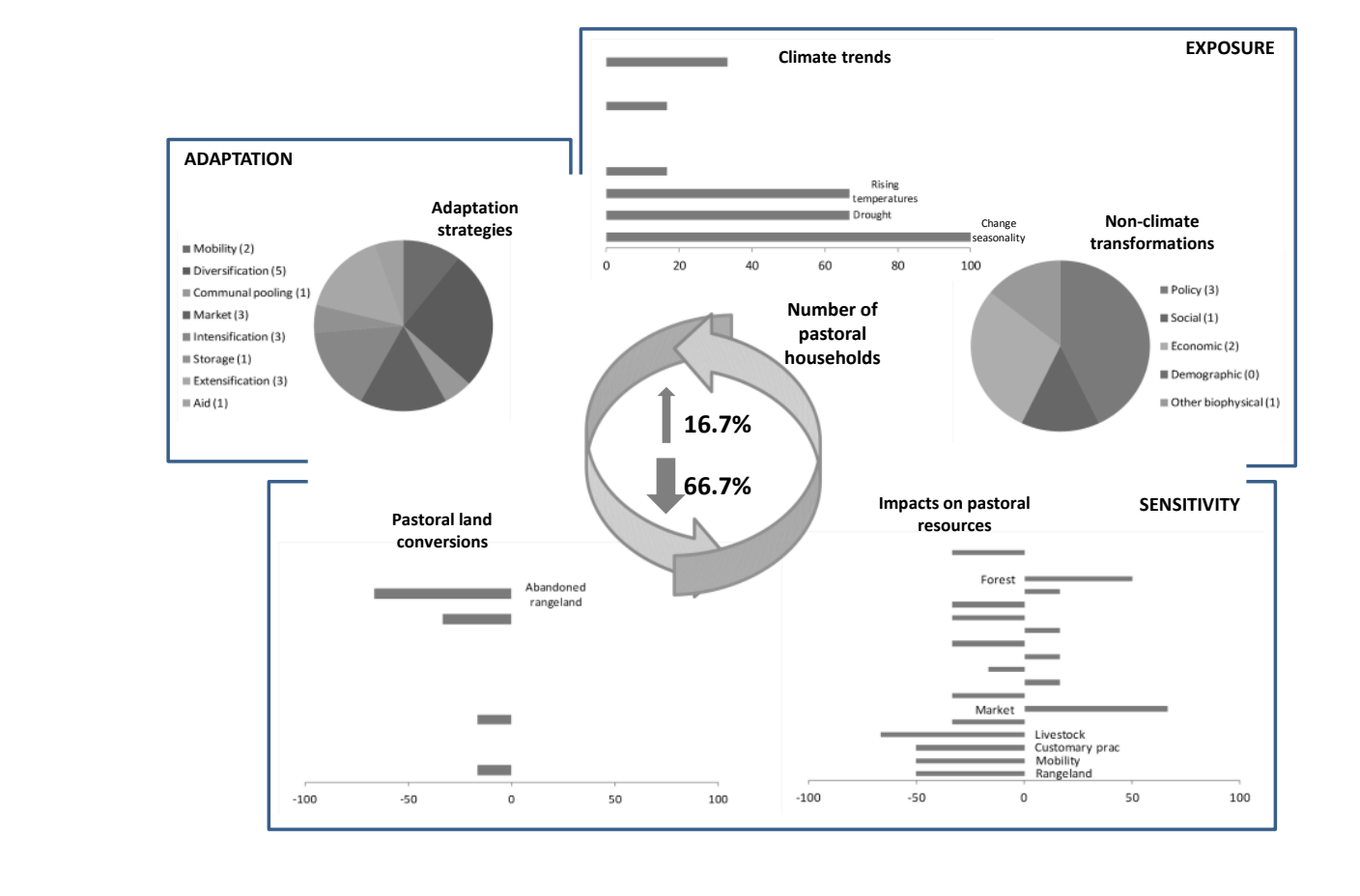

Figure6
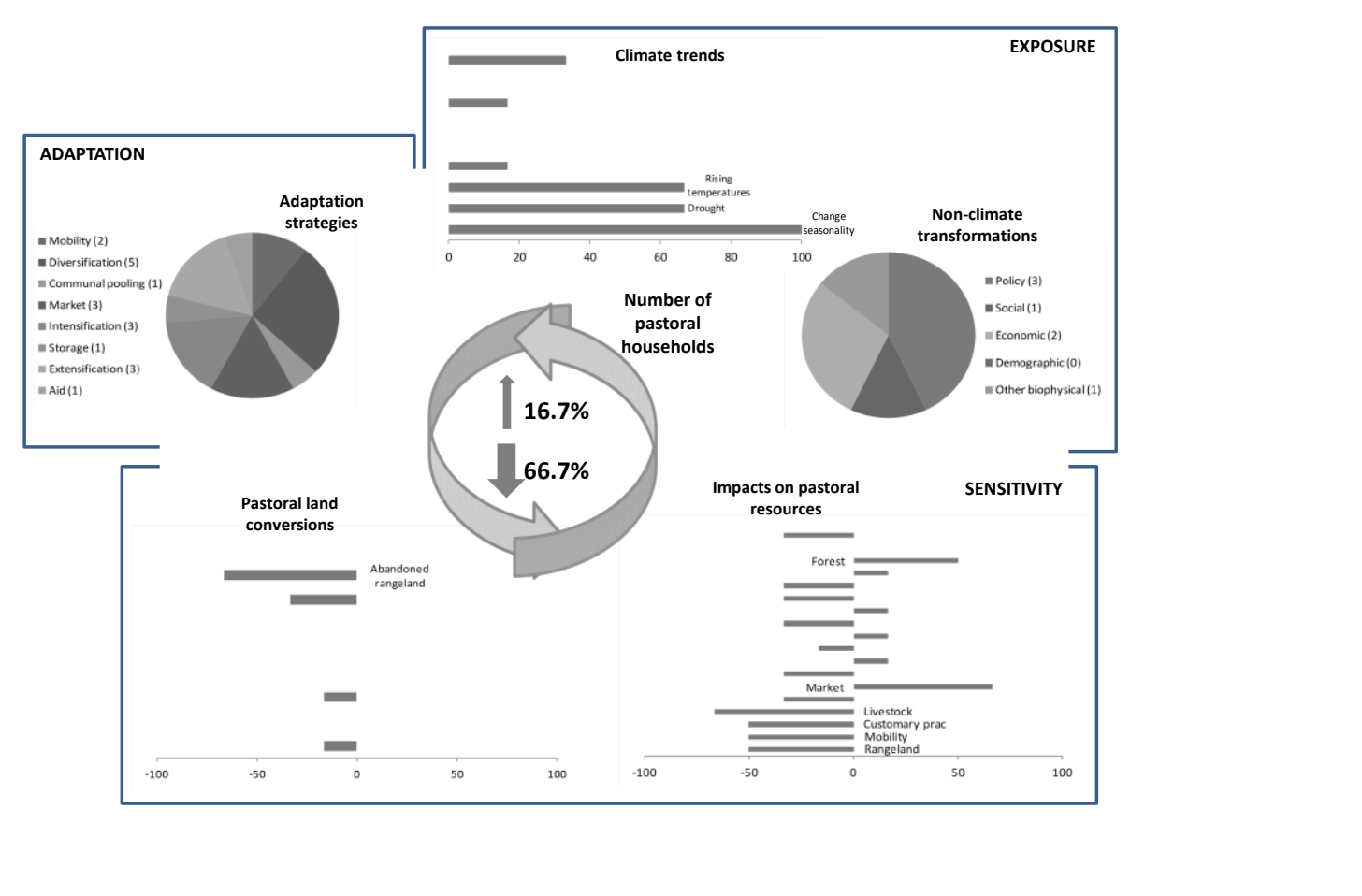


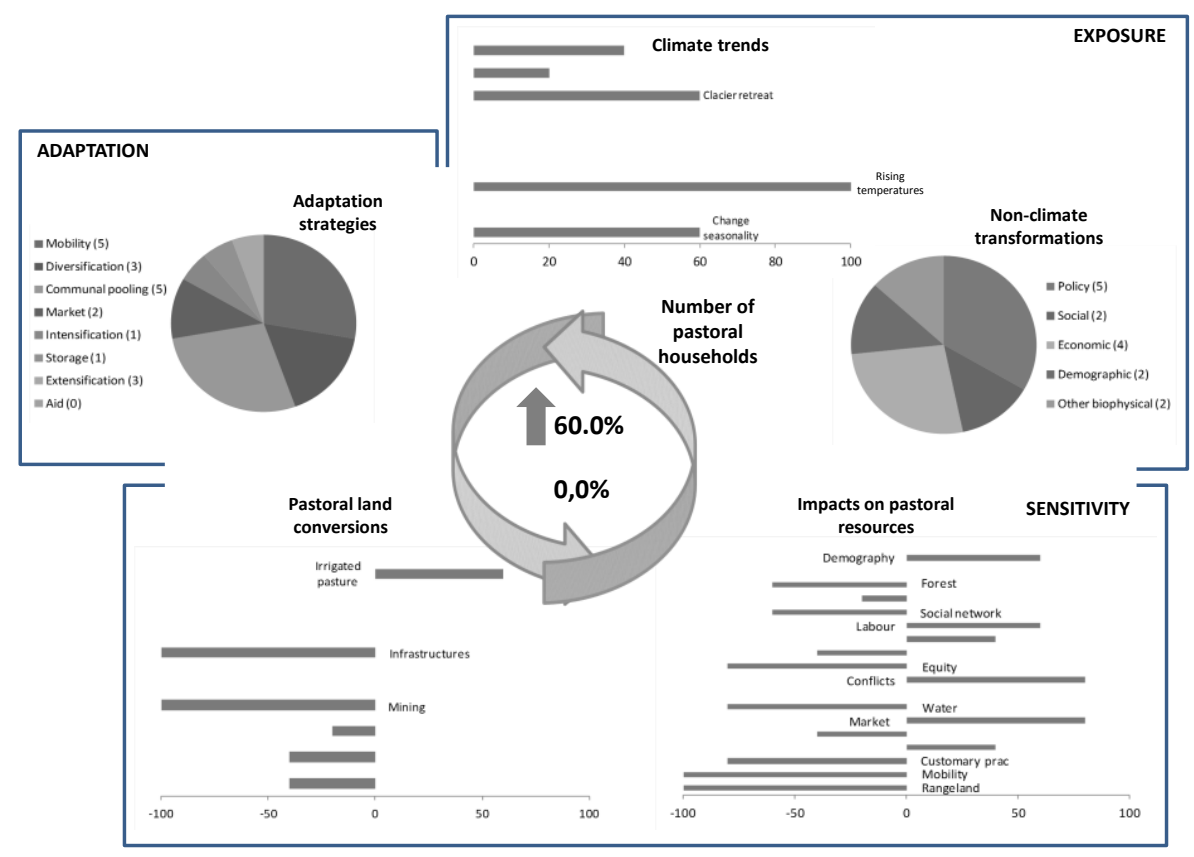




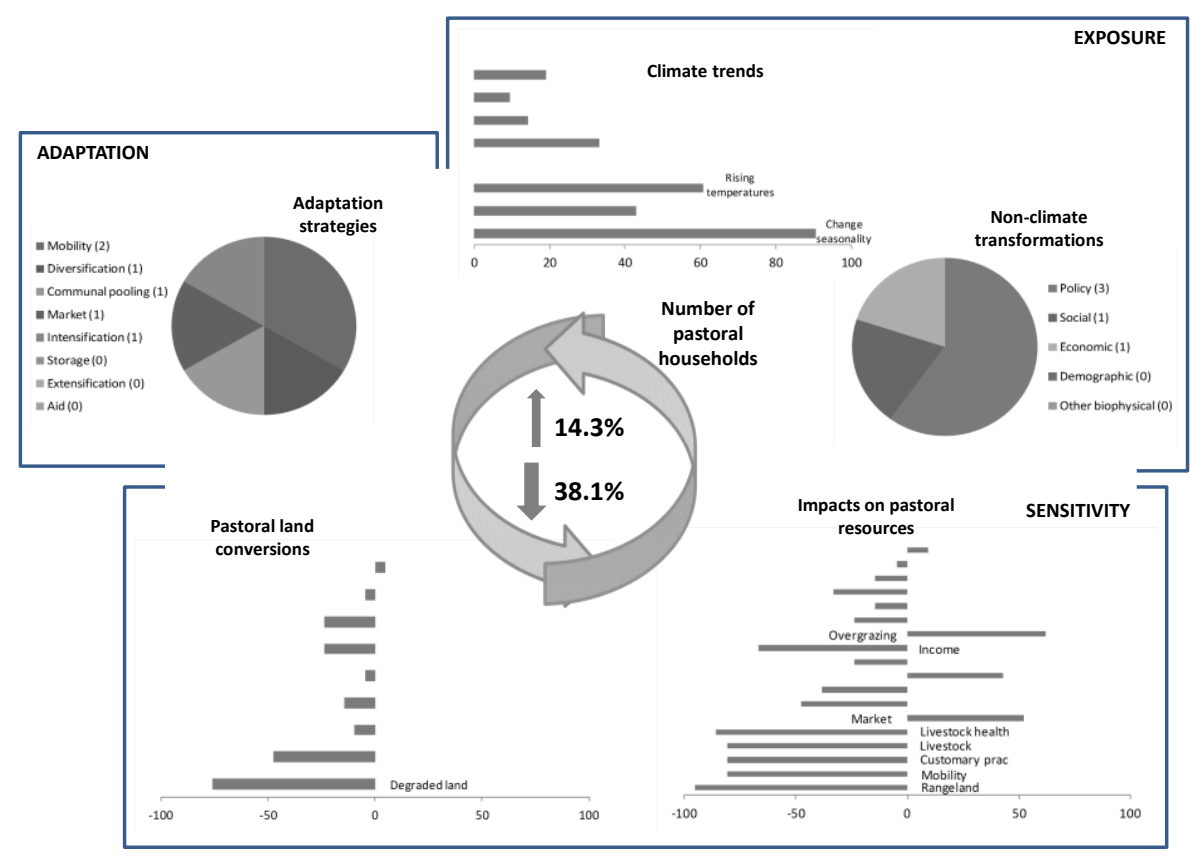




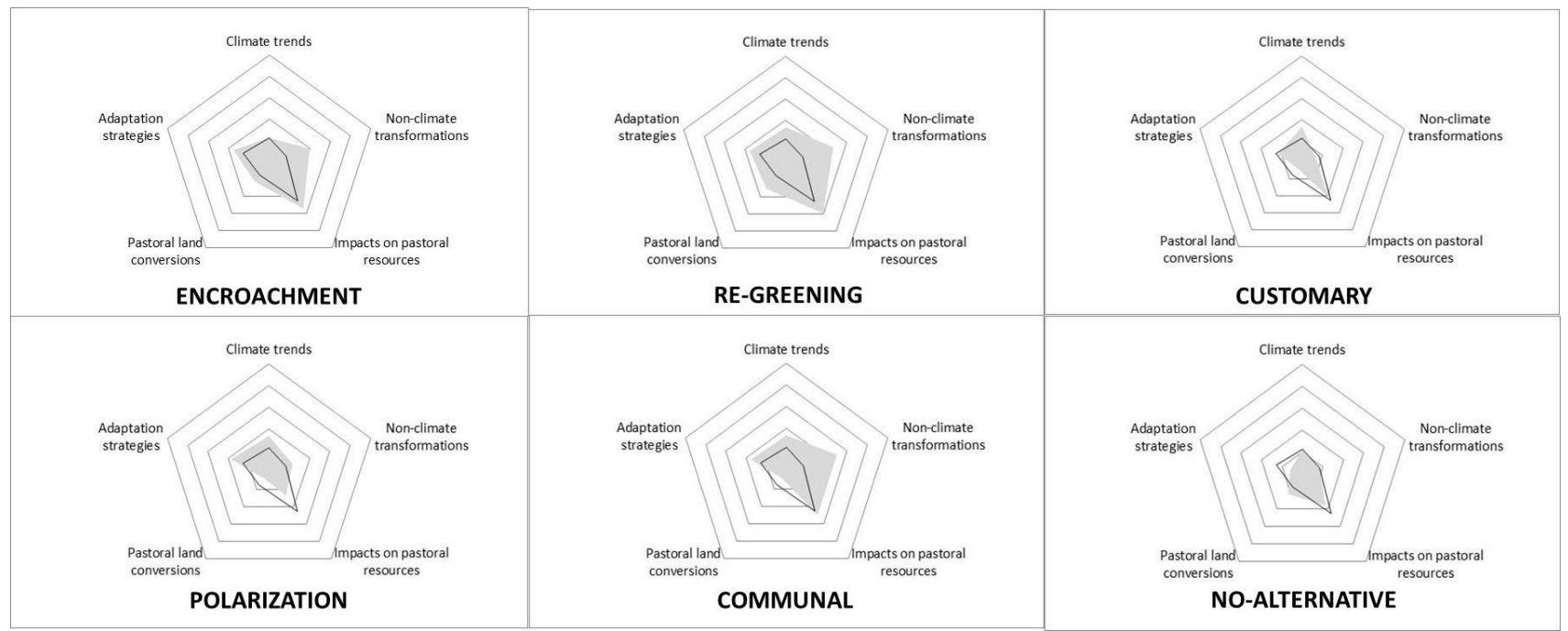




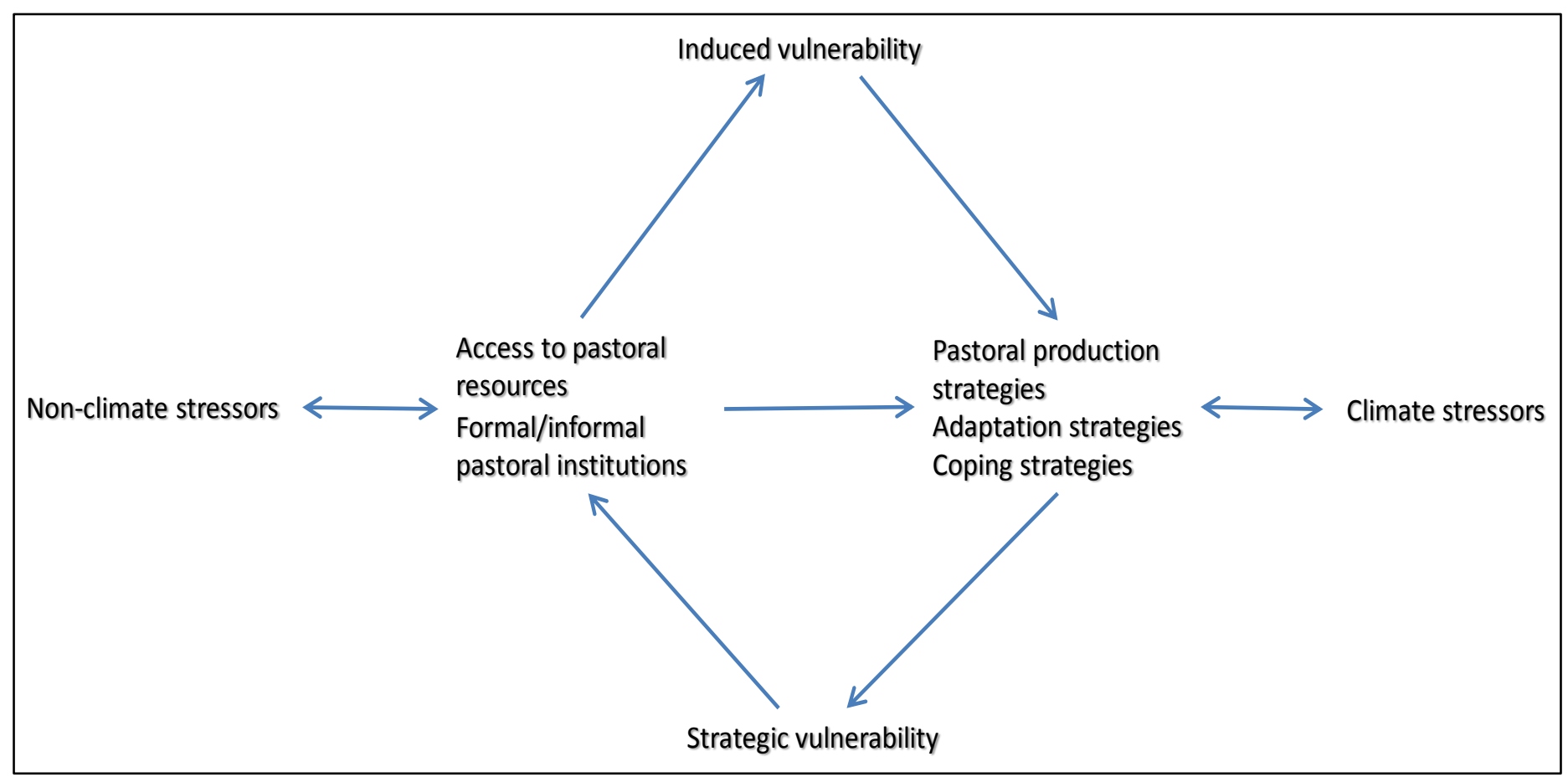


Supplementary Material
Click here to download Supplementary Material for on-line publication only: Supplementary material.doc

Supplementary Material
Click here to download Supplementary Material for on-line publication only: Supplementary material.doc

che (a) (n) publication only: Supplementary materialdoc

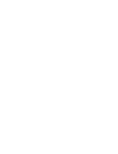
(1)

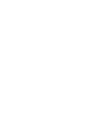
(1)

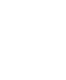
(1) (1) (1) (1)

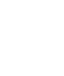
. . . . . . 